This discussion paper is/has been under review for the journal Atmospheric Chemistry and Physics (ACP). Please refer to the corresponding final paper in ACP if available

\title{
Impact of cloud processes on aerosol particle properties: results from two ATR-42 flights in an extended stratocumulus cloud layer during the EUCAARI campaign (2008)
}

S. Crumeyrolle ${ }^{1,2}$, R. Weigel ${ }^{1,3}$, K. Sellegri ${ }^{1}$, G. Roberts ${ }^{4}$, L. Gomes ${ }^{4}$, A. Stohl ${ }^{5}$, P. Laj ${ }^{1,6}$, T. Bourianne ${ }^{4}$, J. M. Etcheberry ${ }^{4}$, P. Villani ${ }^{1,6}$, J. M. Pichon ${ }^{1}$, and A. Schwarzenboeck ${ }^{1}$

${ }^{1}$ Laboratoire de Météorologie Physique, UMR6016, CNRS, Université Blaise Pascal, Clermont-Ferrand, France

${ }^{2}$ NASA Langley Research Center, Hampton, VA 23666, USA

${ }^{3}$ Institute for Physics of the Atmosphere, Johannes Gutenberg University, Mainz, Germany

${ }^{4}$ Centre National de Recherches Météorologiques, Météo-France, Toulouse, URA1357, France

${ }^{5}$ Norwegian Institute for Air Research, Kjeller, Norway

${ }^{6}$ Laboratoire de Glaciologie et Géophysique de l'Environnement, Université de Grenoble 1/CNRS, UMR5183, Grenoble, France
Impact of cloud processes on aerosol particle properties

S. Crumeyrolle et al.

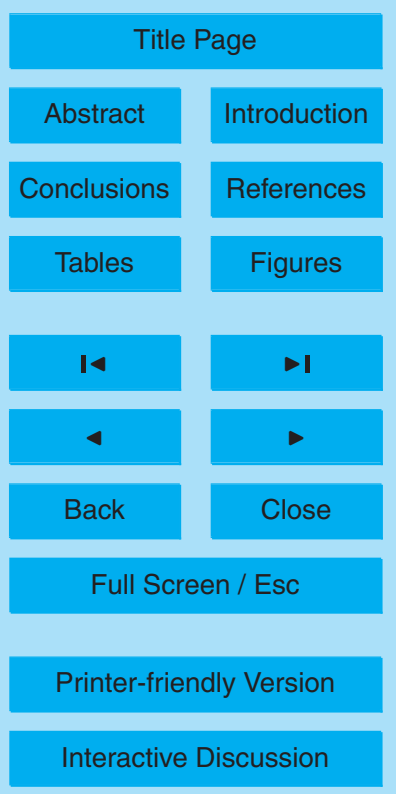

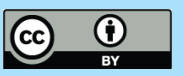


Received: 8 November 2011 - Accepted: 24 November 2011 - Published: 19 December 2011

ACPD

Correspondence to: S. Crumeyrolle (suzanne.crumeyrolle@gmail.com)

Published by Copernicus Publications on behalf of the European Geosciences Union.

Impact of cloud processes on aerosol particle properties

S. Crumeyrolle et al.

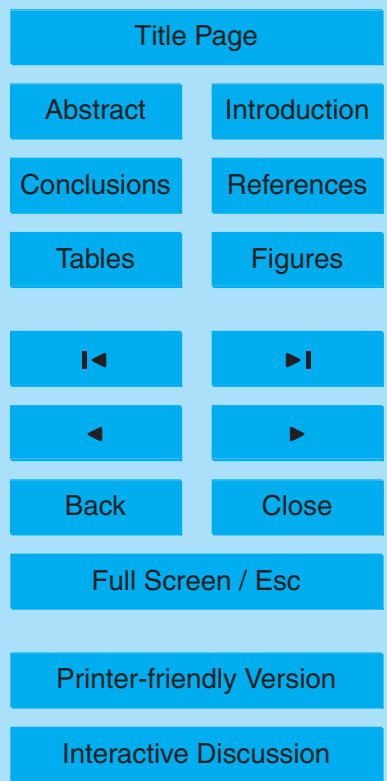

Interactive Discussion

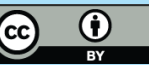




\section{Abstract}

Within the European Aerosol Cloud Climate and Air Quality Interactions (EUCAARI) project, the Meteo France research aircraft ATR-42 was operated from Rotterdam airport during May 2008, to perform scientific flights dedicated to the investigation of

5 aerosol-cloud interactions. Therein, the objective of this study is to illustrate the impact of cloud processing on the aerosol particles physical and chemical properties. The presented results are retrieved from measurements during a double-flight mission from Rotterdam (Netherlands) to Newcastle (UK) and back using data measured with compact Time of Flight Aerosol Mass Spectrometer (cToF-AMS) and Scanning 10 Mobility Particle Sizer (SMPS). Cloud-related measurements during these flights were performed over the North Sea within as well as in close vicinity of a marine stratocumulus cloud layer. Particle physical and chemical properties observed in the close vicinity $(\mathrm{V})$, below and above the stratocumulus cloud show strong differences. Firstly, measurements at constant altitude above the cloud layer show decreasing mass con15 centrations with decreasing horizontal distance $(210-0 \mathrm{~km})$ to the cloud layer by a factor up to 7 , whereas below the cloud and by same means of distance, the mass concentrations merely decrease by a factor of 2 on average. Secondly, the averaged aerosol size distributions, observed above and below the cloud layer, are of bimodal character with pronounced minima between Aitken and accumulation mode which is potentially the consequence of cloud processing. Finally, the chemical composition of aerosol particles is strongly dependent on the location relative to the cloud layer (vicinity or below/above cloud). In general, the nitrate and organic fractions decrease with decreasing distance to the cloud, in the transit from cloud-free conditions towards the cloud boundaries. The decrease of nitrate and organic compounds ranges at a factor of three to ten, affecting sulfate and ammonium compounds to be increasingly abundant in the aerosol chemical composition while approaching the cloud layer. Finally, the chemical composition of non-refractory evaporated cloud droplets measured within the cloud shows increased fractions of nitrate and organics (with respect to concentrations

\section{Impact of cloud processes on aerosol particle properties}

S. Crumeyrolle et al.

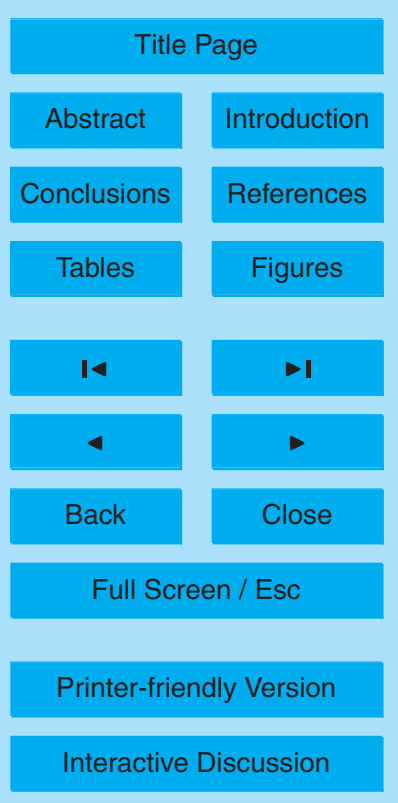 \\ 33231}


found below clouds), but also large amounts of sulfate, thus, related to activation of particles, made up of soluble compounds.

\section{Introduction}

Aerosols originate either from natural sources (e.g. mineral dust, sea salt, ash, bio5 genic aerosol or ablation material of meteorites) or from emissions by anthropogenic activities (e.g. soot, smoke, and other traffic or industrial emissions, e.g. lead or mercury particles, Murphy et al., 1998). Those aerosol particles which undergo long range transport may have a particularly strong influence on the climate directly by absorbing and reflecting shortwave solar radiation (Haywood et al., 2003; Intergovernmental 10 Panel on Climate Change, 2007) and indirectly by modification of cloud structure as well as their microphysical properties (Lohmann et al., 2004).

Aerosol activation to form cloud droplets is the direct microphysical link between aerosols and clouds, and is at the origin of the indirect effect (Nenes and Seinfeld, 2003). The Köhler theory (Köhler, 1936) considers curvature and solute effects on

15 the equilibrium vapor pressure of a growing droplet. This equilibrium curve shows supersaturation maxima, known as critical supersaturation $\left(s_{\mathrm{c}}\right)$, at a critical droplet diameter $\left(D_{\mathrm{c}}\right)$. When this equilibrium becomes unstable, i.e. particles are exposed to supersaturation above $s_{\mathrm{c}}$ for the time needed to reach $D_{\mathrm{c}}$, particles act as cloud condensation nuclei (CCN) and become cloud droplets (Nenes et al., 2001; Chuang 20 et al., 1997).

Aerosol-cloud interactions depend on aerosol particle properties such as number concentration, size, chemical composition, hygroscopic properties and mixing state (Roberts et al., 2001; Sellegri et al., 2003; Cubison et al., 2008; Wang et al., 2010). In addition, the interaction depends on the type of involved clouds, including continental or maritime, convective or stratiform, and liquid or ice phase clouds (Reutter et al., 2009, Andrejczuk et al., 2010). Atmospheric aerosol particles affect cloud formation by acting as CCN and ice nuclei (IN) (Harrison, 2000).

\section{Impact of cloud processes on aerosol particle properties}

S. Crumeyrolle et al.

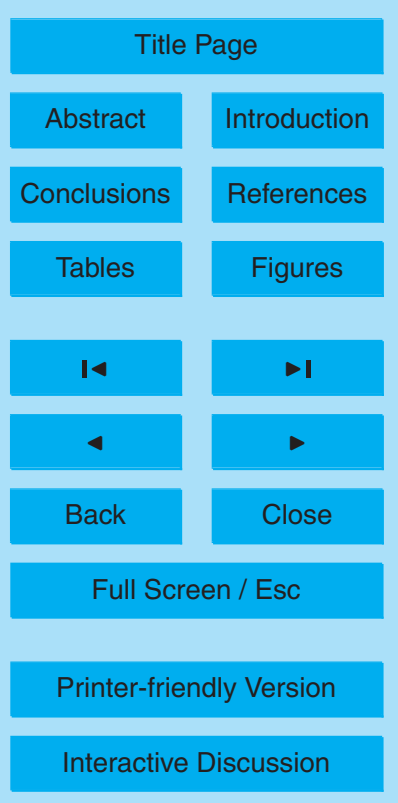


In return, aerosol properties are modified by in-cloud processes (Hoppel et al., 1994; Levin et al., 1996). Cloud processing affects aerosol particle number concentration, particle size and chemical composition due to particle dissolution and subsequent transformation processes which may cause chemical reactions in the cloud liquid 5 phase. Heterogeneous reactions in the liquid phase and uptake of gases into droplets lead to further processing of CCN particulate matter.

Prominent studies related to the impact of cloud processing on the evolution of aerosol properties have been performed previously and include field observations, laboratory measurements, and modelling studies. Levin et al. (1996) studied effects of 10 cloud processing of mineral dust and sulfate and found that dust particles may be coated with sulfate due to in-cloud processing. Results obtained from modelling studies also highlight the role of clouds in modifying aerosols. For example, Yin et al. (2002) used a numerical model to show that even insoluble particles like mineral dust may become effective CCN after in-cloud processing in a convective cloud. Furthermore, this study showed that the uptake of gases into droplets and subsequent oxidation of gases in the liquid phase could add considerable amounts of soluble material (sulfate, nitrate) to the dust particles. Wurzler et al. (2000) showed that cloud processing is an effective pathway to form soluble coatings on dust particles. Even without cloud processing, aerosol particles may become more active CCN- through oxidation of organic species or due to heterogeneous chemical processes (George and Abbatt, 2010; Sullivan et al., 2009; Roberts et al., 2010).

Experimental evidences of cloud processing of aerosol particles are rare and were often limited to ground-based studies on orographic clouds (Bower et al., 1997). Hill-top clouds are specific clouds that form when supersaturation is driven by orography and which are often very large comparedwith respect to other type of clouds, in particular marine stratocumulus clouds. Marine boundary layer clouds cover a large fraction of the planetary ocean ( $30 \%$ according to Warren et al., 1988) and their albedo is about 10 times larger than the one of the underlying dark ocean surface. This means that they are a crucial component of the Earth's radiation budget (Hartmann et al., 1992).

\section{ACPD}

11, 33229-33271, 2011

\section{Impact of cloud processes on aerosol particle properties}

S. Crumeyrolle et al.

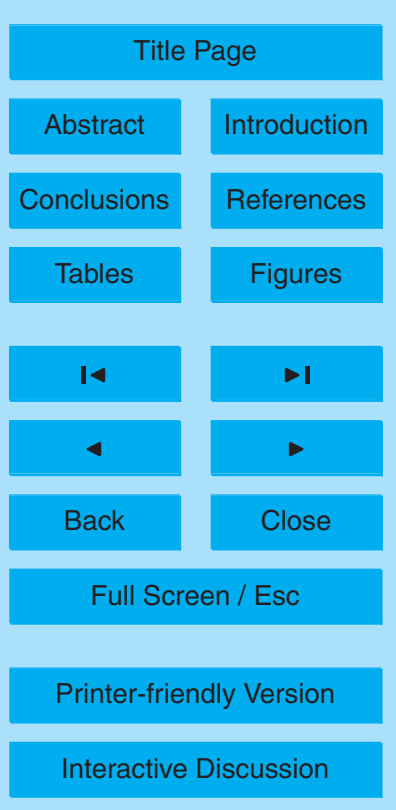

Interactive Discussion 
The study of clouds impacting aerosol properties presented here is based on airborne measurements that were conducted in the framework of the European Aerosol Cloud Climate and Air Quality Interactions (EUCAARI; Kulmala et al., 2009, 2011) project.

\section{Experimental strategy and instrumentation}

5 The EUCAARI project was designed to improve our knowledge on processes related to atmospheric aerosol physics and chemistry, from the nanometer scale to the overall aerosol-cloud-climate scale. Within the project an intensive measurement campaign dedicated to aerosol and cloud studies was carried out between the 1 and 31 May 2008 in the Netherlands including both airborne and ground measurements. The ATR-

1042 research aircraft, operated by SAFIRE (Service des Avions Français Instrumenté pour la Recherche en Environnement), was based at the Rotterdam airport and was equipped with comprehensive scientific instrumentation to perform aerosol-cloud studies (Crumeyrolle et al., 2008; Matsuki et al., 2010). A total of 22 research flights were performed between 2 May and 30 May 2008 (Crumeyrolle et al., 2010). In this study, 15 we will focus on two cloud research flights performed on 15 May 2008 over the North Sea from Rotterdam to Newcastle during the morning (06:19-09:50 UTC) and the return flight from Newcastle to Rotterdam during the afternoon (11:49-15:06 UTC). The rather similar flight trajectories of these two flights are presented in Fig. 1.

In the same figure the brightness temperature, from MODIS satellite documents, 20 indicates the presence of the stratocumulus field that was studied in the northern part of the domain. Furthermore, the presence of cirrus in the southern part is indicated. Remote sensing observations, performed by the nadir-looking RASTA radar (Protat et al., 2004) on board the ATR-42, were used to specify the precipitating or non-precipitating character of this stratocumulus. The radar reflectivities were similar 25 (about $-20 \mathrm{dBZ}$ ) during the morning and afternoon flights and the associated mean Doppler velocity was between -2 and $-4 \mathrm{~m} \mathrm{~s}^{-1}$. The reflectivities are characteristic for drizzle regime. Nevertheless, drizzle drops reached lower altitudes during the morning

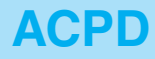

11, 33229-33271, 2011

\section{Impact of cloud processes on aerosol particle properties}

S. Crumeyrolle et al.

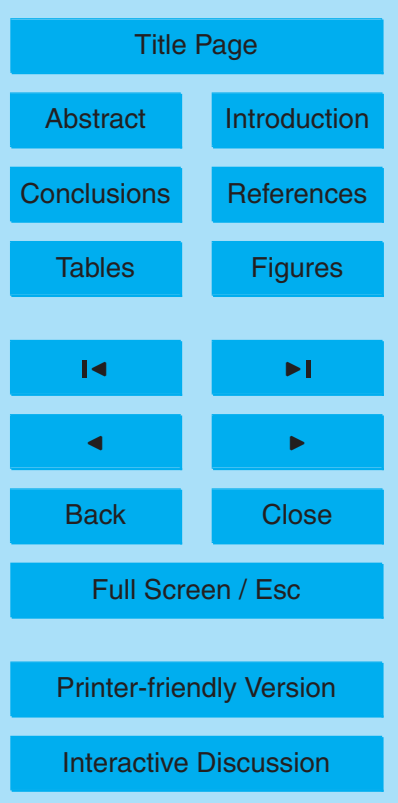


(down to $300 \mathrm{~m}$ a.s.l.) than during the afternoon (down to $500 \mathrm{~m}$ a.s.l.) before they evaporated.

The ATR-42 was equipped with the Community Aerosol Inlet (CAI) for aerosol measurements in cloud-free conditions and a Counterflow Virtual Impactor (CVI, Ogren

5 et al., 1985; Schwarzenboeck et al., 2000) that was used during in-cloud measurements. The CVI is designed to exclusively collect cloud elements (cloud droplets and ice crystals; $D>5 \mu \mathrm{m}$ of aerodynamic particle diameter), while essentially rejecting interstitial aerosol particles. As shown in Sellegri et al. (2003), the efficiency coefficient was obtained by comparing in cloud concentrations, cloud-free concentrations, and 10 whole air concentrations. As these concentrations were not observed simultaneously in our study, the efficiency of the CVI probe could not be calculated. The isokinetic CAI is based on the University of Hawaï shrouded solid diffuser inlet designed by A. Clarke (personal communication) and modified by Meteo France. The CAI inlet allows for sampling submicron and partly supermicron particles with an upper $50 \%$ sampling 15 efficiency for particle sizes at $D \sim 5 \mu \mathrm{m}$ (McNaughton et al., 2007). Thus, switching between the CVI during in-cloud conditions and the CAI in cloud-free conditions allowed for direct sampling of either the cloud residual or cloud free total aerosol particles.

Two Scanning Mobility Particle Sizers (SMPS) measured size distributions between 20-500 nm diameter of particles entering the CAI probe: one SMPS was operated at ambient conditions and the second SMPS measured downstream of a denuder heating the aerosol up to $280^{\circ} \mathrm{C}$. The SMPS systems consisted of a Krypton aerosol neutralizer (Kr-85), a DMA (Differential Mobility Analyzer) as described by Villani et al. (2007) and a TSI model 3010 condensation particle counter. Typically, the time span for the SMPS to scan over the complete detectable size range from 20-500 nm was set to $90 \mathrm{~s}$.

25 An Aerodyne compact Time of Flight Aerosol Mass Spectrometer (cToF-AMS; Drewnick et al., 2005; Canagaratna et al., 2007) was applied for the EUCAARI mission to analyse in quasi-real time the chemical composition of the non-refractory aerosol particles entering the $\mathrm{CAI}$ and $\mathrm{CVI}$ probes. The notation non-refractory includes all species that evaporate in a few milliseconds at a temperature of $\sim 600^{\circ} \mathrm{C}$. In practice,

\section{ACPD}

11, 33229-33271, 2011

\section{Impact of cloud processes on aerosol particle properties}

S. Crumeyrolle et al.

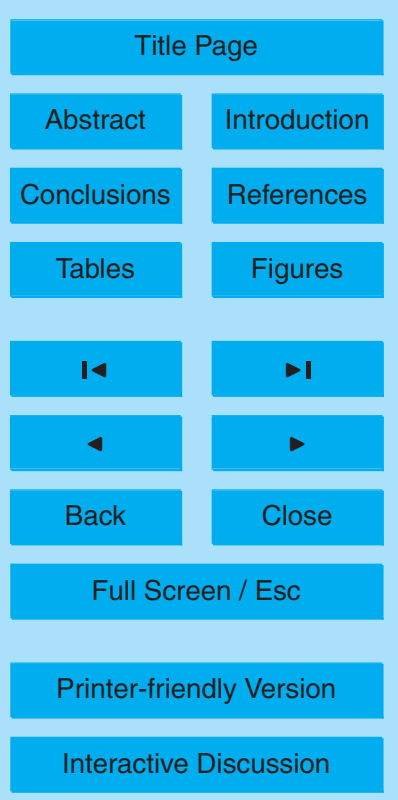


cToF-AMS measurements exclude the detection of black carbon, crustal materials, and sea salt/sodium chloride. Thus, even a fraction of non-refractory species internally mixed with refractory species (e.g., organics internally mixed with black carbon) can be quantitatively detected with the AMS (Katrib et al., 2005; Slowik et al., 2004).

5 The non-refractory particle species that are vaporized are then subjected to electron impact (El) ionization, which forms positive ions that are analyzed using a Time-ofFlight mass spectrometer. For typical accumulation mode particles, the sampling efficiency (predominantly limited by the aerodynamic lens; Zhang et al., 2004) is close to $100 \%$ and the AMS quantitatively measures mass loadings (Liu et al., 2007). Lab10 oratory measurements showed that particle diameters larger than $800 \mathrm{~nm}$ are not detected anymore with our CToF-AMS, whereas particles with $600 \mathrm{~nm}$ in diameter are assumed to be detected with efficiency close to $100 \%$. The cToF-AMS used during EUCAARI/IMPACT was additionally equipped with a Pressure Controlled Inlet (PCI), similarly to the system described by Bahreini et al. (2008). The temporal resolution 15 of the ToF-AMS measurement throughout the EUCAARI mission was set to $\sim 23 \mathrm{~s}$. Generally, ToF-AMS measurements deliver size segregated aerosol chemical composition with alternating operation modes, the Particle Time of Flight (PToF) and the Mass Spectrometer (MS) mode. Due to a not further identified instrumental malfunction in the particle sizing PToF mode of our cToF-AMS this study focuses on the measurement in the MS mode (10 s sampling time, $23 \mathrm{~s}$ temporal resolution) delivering exclusively the non-refractory aerosol chemical composition over the entire AMS measurement size range.

Thus, the aerosol size distribution (SMPS), as well as the non-refractory aerosol chemical composition (cToF-AMS), is measured simultaneously during cloud-free periods while only aerosol chemical composition is measured during "in-cloud" periods. This latter fact is due to the SMPS scan durations that are not adapted for use in heterogeneous cloud fields with the CVI inlet. In order to validate the data set, mass concentrations derived from the size distribution measurements (SMPS and PCASP) and AMS measured mass concentrations were compared and found to be in appropriate

\section{Impact of cloud processes on aerosol particle properties}

S. Crumeyrolle et al.

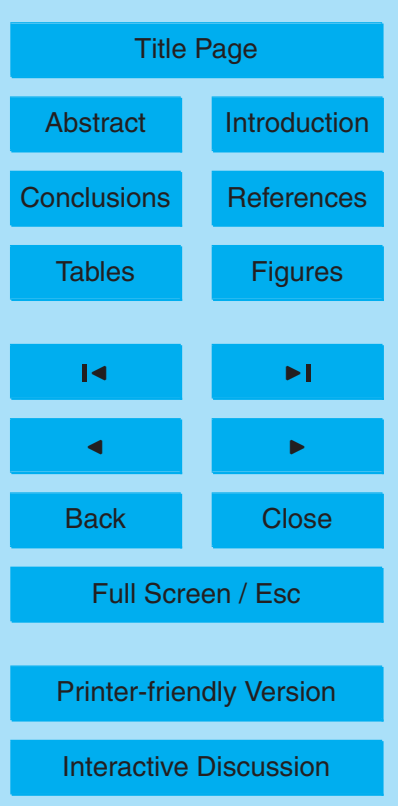




\section{Results}

For this study, we selected two research flights (RF51 and RF52) where measurements were performed in- and outside a stratocumulus cloud layer on 15 May 2008, thus 5 particularly dedicated to the study of aerosol-cloud interactions. The vertical extension of the stratocumulus clouds was between 300 and $1100 \mathrm{~m}$ a.s.l. During both flights the ATR-42 performed ascents and descents during clear sky periods over the North Sea which provided a rapid characterization of the inversion level and of the vertical profile of the thermodynamical and microphysical parameters. The inversion level was found to be on average around $900 \mathrm{~m}$ in altitude during the morning and around $1000 \mathrm{~m}$ in the afternoon. In order to characterize the interaction of aerosol particles with clouds, we start with comparing particle physico-chemical properties observed inside the cloud layer with those observed outside the cloud at corresponding flight altitudes.

The different flight segments related to the stratocumulus (sc) cloud layer are repre15 sented in Fig. 2: green segments correspond to cloud-free periods named sc-vicinity, black segments to measurements below/above cloud layer, whereas purple segments correspond to "in-cloud" measurements sampling the cloud residual aerosol via the $\mathrm{CVI}$ inlet. For each flight segment, respective time period, segment position relative to the cloud layer, flight altitude as well as the equivalent potential temperature are listed in Table 1 (morning flight, RF51) and Table 2 (afternoon flight, RF52).

In order to determine the transport pathways of the sampled air masses we used the FLEXPART model (Stohl et al., 1998, 2005). The model revealed that air masses sampled with the ATR-42 on 15 May 2008 approached the air sector of measurements across the North Sea during the morning (RF51) and also the afternoon flight (RF52,

25 Fig. 3). The wind direction and wind speed observed on board the ATR-42 within specific flight segments are illustrated in Fig. 4. The prevailing wind directions for both flights were between North and East, as derived from FLEXPART calculated air mass

\section{Impact of cloud processes on aerosol particle properties}

S. Crumeyrolle et al.

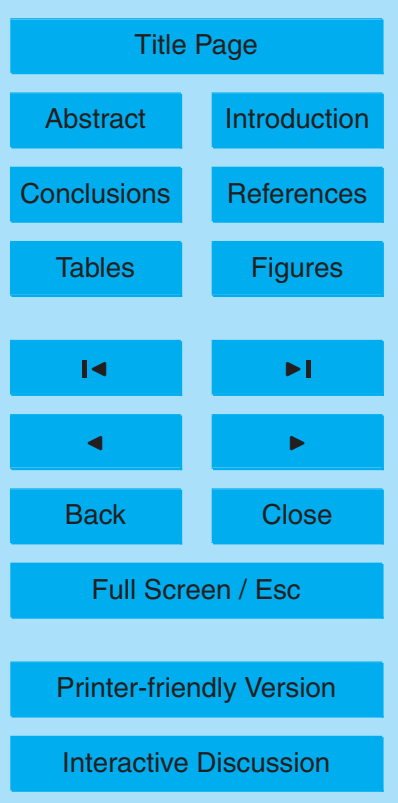


pathways. Exceptional is one afternoon flight segment (V2) during which the wind direction was inverted (direction between South and West). This probably caused the advection of aerosol of changed properties as it was locally most likely influenced by anthropogenic emissions. Therefore, the flight segment V2 cannot be used to study 5 interactions between aerosol and clouds in the main North-East flow. As these wind conditions during V2 are locally very limited (i.e. $\sim 10 \mathrm{~km}$ of flight distance) and as these correspond to a very short time period, this is not captured by these micro-scale features resolved by the FLEXPART tool.

Two air masses are assumed to be almost similarly composed, if their equivalent 10 potential temperatures $\left(\theta_{\mathrm{e}}\right)$ - the natural logarithm of $\theta_{\mathrm{e}}$ is proportional to the entropy of moist air, thus $\theta_{\mathrm{e}}$ is a measure of instability of air at $p, T, q$ and $\mathrm{RH}$ - are within a few kelvin. Hence, $\theta_{e}$ is a conservative parameter for an air parcel moving along moist isentropic surfaces. This allows evaluating air masses with respect to their state of mixture. An identical $\theta_{\mathrm{e}}$ indicates air masses with almost identical origin, identical 15 strength of processing and particularly often homogeneously mixed conditions inside the air parcel. In our study, the comparison of $\theta_{\mathrm{e}}$ at different altitudes $\left(\theta_{\mathrm{e}}\right.$ below $600 \mathrm{~m}$ and above $1000 \mathrm{~m}$ ), shows significant differences ( $>5 \mathrm{~K}$ in average), suggesting differences in air mass history and possibly in their gaseous and aerosol concentrations and composition. Two principal aerosol layers are distinguished here, as there are the boundary layer and the free troposphere. In the boundary layer, a rather stable $\theta_{\mathrm{e}}$ is observed, consistent with a well-mixed layer, thus, demonstrating that the analyzed air masses have similar recent history. Therefore, they are most likely of similar gaseous and aerosol composition. At higher levels $(>1000 \mathrm{~m})$, excluding south-west wind periods (V2) (cf. previous section) the horizontal variability of $\theta_{\mathrm{e}}$ is large (25 K and $14 \mathrm{~K}$ for RF51 and RF52, respectively) due to a range of values of $\theta_{\mathrm{e}}$ observed during two periods ( $\mathrm{V} 1$ and $\mathrm{C} 4$ ) for the morning flight and one period (C13) for the afternoon flight. These results suggest that air masses for the three periods (i.e. V1, C4 and C13) have encountered particularly different types of air masses concerning their aerosol composition, state of aerosol processing or grade of aging.

\section{Impact of cloud processes on aerosol particle properties}

S. Crumeyrolle et al.

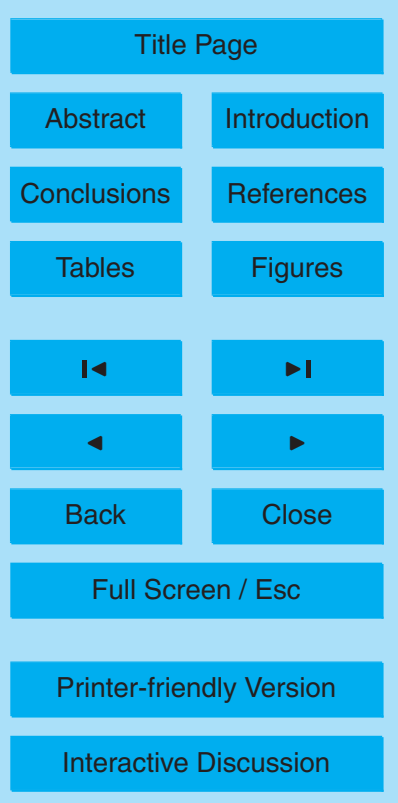


The most important measurements for this study were those of particle number size distributions and aerosol chemical composition. Subsequently aerosol particle size spectra and chemical composition were analysed at different locations, with respect to the cloud layer, to estimate the impact of cloud processing on the phase partition5 ing of aerosol particles and aerosol activation by comparing aerosol properties in the sc-vicinity, in the boundary layer and inside clouds. The influence of precipitation scavenging of drizzle clouds on aerosol particles as well as cloud processing is assessed by comparing aerosol properties in the sc-vicinity at lower level (BL) and below the cloud layer at comparable altitude.

\subsection{Aerosol particle size distributions}

SMPS submicron aerosol size distributions were processed, taking into account the particles electrical charging probabilities, the CPC counting efficiencies and the DMA transfer functions. The number size distributions that were measured continuously during each flight were averaged over specific periods (see Tables 1 and 2 as well 15 as Fig. 2 for the predefined periods), in order to produce a mean particle number size distribution for each period. Subsequently mean volume size distributions were calculated from the mean number size distributions. The mean (number and volume) size distributions were fitted by using multi-modal log-normal distributions that best represent the measured distributions. Herein, a maximum of four modes was employed 20 to describe the number distributions with sufficient detail. The parameters of each mode of the log-normal fit (number concentration, median diameter and geometric standard deviation) are shown in Table 3 (RF51) and in the Table 4 (RF52), respectively. These fitted number size distributions are graphically presented in Fig. 5.

Aitken (Particule Diameter $\left.\left(D_{\mathrm{p}}\right)<0.1 \mu \mathrm{m}\right)$ and accumulation $\left(0.1<D_{\mathrm{p}}<0.5 \mu \mathrm{m}\right)$ 25 modes were identified in the boundary layer and in the free troposphere. The size distribution characteristics varied significantly as a function of sampling period and sampling altitude.

Looking first at research flight RF51 (Fig. 5a), a comparison of the averaged number 33239

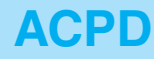

11, 33229-33271, 2011

\section{Impact of cloud processes on aerosol particle properties}

S. Crumeyrolle et al.

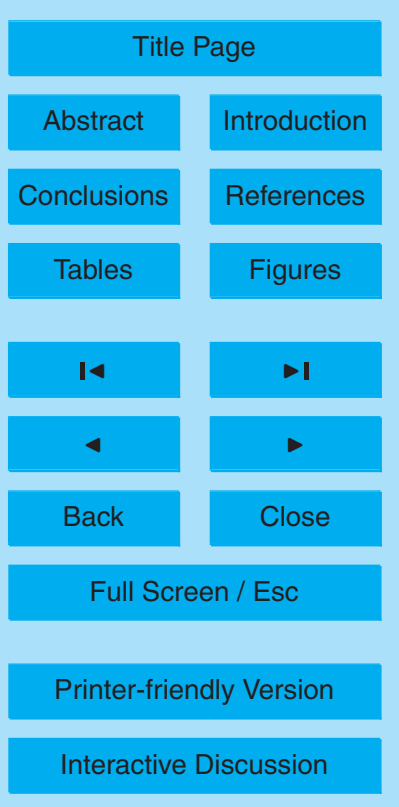


size distributions for each period reveals significant differences, consistent with the presence of two distinct air mass layers (also seen from differences in the equivalent potential temperature):

a) Boundary layer (all segments below the temperature inversion altitude) in the vicinity of clouds, the size distribution is clearly bimodal with distinct Aitken and accumulation particle modes. Inbetween these two modes there is a pronounced minimum, known as the "Hoppel minimum" (Hoppel et al., 1994, 1986) and potentially related to in-cloud aerosol processing and activation processes, principalis observed between 70 and $90 \mathrm{~nm}$. This diameter range corresponds to an effective maximum supersaturation (Fitzgerald et al., 1998; Feingold et al., 1996) achieved in this stratocumulus. The Hoppel minimum is more apparent during the "belowcloud" cases compared to corresponding altitudes of sc-vicinity periods.

Moreover, the mean diameter of the accumulation mode of aerosol particles below the cloud layer reached $223 \mathrm{~nm}$ while the mean diameter at corresponding altitudes within sc-vicinity periods was ranged at about $177 \mathrm{~nm}$. The geometric standard deviations of the fitted accumulation mode are small $(<1.44)$ and decrease below the cloud layer. This narrow accumulation mode may be a result of below-cloud scanvenging of larger particles. The increase of the mean diameter with decreasing distance to the cloud might be due to cloud processing including drizzle evaporation below the cloud. In contrast, the concentration of particles in the accumulation mode size range decreases above the cloud layer as compared to corresponding altitudes of sc-vicinity periods, indicating that particles are entrained from above (Clarke et al., 1999) and may even contribute to the below-cloud aerosol after drizzle droplet evaporation.

b) Free troposphere (all segments above the temperature inversion altitude): Compared to the boundary layer, in the free troposphere the size distribution modes move from $147 \mathrm{~nm}$ and $234 \mathrm{~nm}$ (periods V1 and V2) during sc-vicinity periods to a single mode distribution at $88.3 \mathrm{~nm}$ at corresponding above-cloud altitudes. The

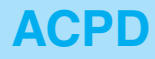

11, 33229-33271, 2011

\section{Impact of cloud processes on aerosol particle properties}

S. Crumeyrolle et al.

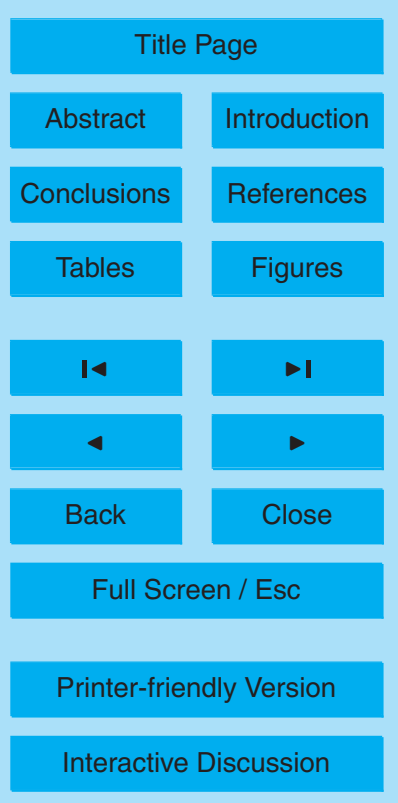


entrainment of air masses into the cloud layer seems to have an effective impact within a layer of $200 \mathrm{~m}$ above the cloud top. Thus, entrainment of dry air into the cloud might lead to the trapping of larger particles. Indeed, larger particles from the layer just above the cloud could be trapped in the cloud layer due to activation, rain out and collision process (Jiang et al., 2002). Puygrenier et al. (2012) showed that a considerable variability of thermodynamic parameters, such as temperature and humidity, observed in the layer $200 \mathrm{~m}$ above this stratiform cloud is due to the mixing of moist and cold air from the cloud layer with dry and warm air from the free troposphere. Therefore the measurements immediately above the cloud layer are not representative for the free troposphere but rather for the inversion layer above cloud top - a kind of transition region which is influenced by cloud related processes.

The observations which were made during the second research flight RF52 (Fig. 5b) were similar. The measurement results show less accumulation mode particles above the cloud layer and enhanced number and larger sizes of accumulation mode particles below the cloud layer as compared to the cloud free conditions (sc-vicinity). With respect to cloud processes (activation, cloud processing, entrainment, precipitation), as already observed for RF51, a minimum between Aitken and accumulation mode is observed in the proximity to the cloud ( $\mathrm{V}$ periods), as well as an increase of the mean diameter of the accumulation mode with decreasing distance to the cloud. An additional nucleation mode appears to be present in the aerosol size distribution at lower level below the cloud base.

\subsection{Mass concentrations}

\subsection{1 "Near-cloud" measurements}

25 Figure 6 show the aerosol mass concentrations measured by the cToF-AMS for the morning flight (RF51) and the afternoon flight (RF52). The mass concentrations of non-refractory particles are presented for the different segments of sc-vicinity and 33241

\section{1, 33229-33271, 2011}

\section{Impact of cloud processes on aerosol particle properties}

S. Crumeyrolle et al.

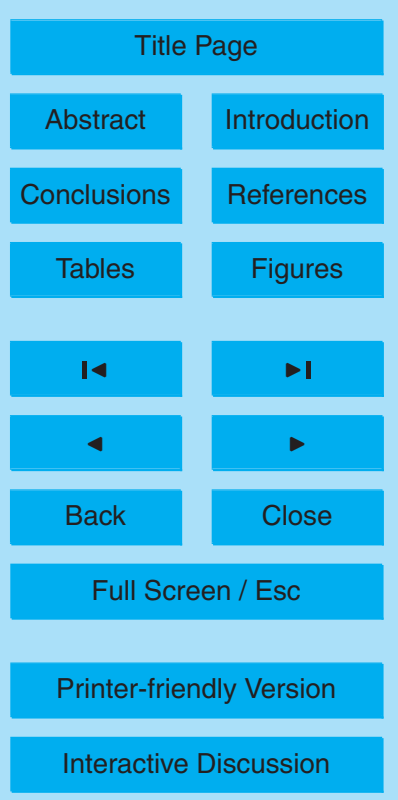

Interactive Discussion 
above/below the stratocumulus layer for both layers (BL, FT). Concentration tendencies observed on the aerosol size distributions (SMPS) are coherent with the tendencies observed on the aerosol mass concentrations (cToF-AMS).

In the boundary layer $(<1000 \mathrm{~m})$, the median mass concentrations are less than $512.1 \mathrm{\mu g} \mathrm{m}^{-3}$. During the morning flight (RF51), the observed mass concentrations decreased as the aircraft approaches the cloud with (i): $11.66 \pm 0.3 \mu \mathrm{g} \mathrm{m}^{-3}$ in sc-vicinity

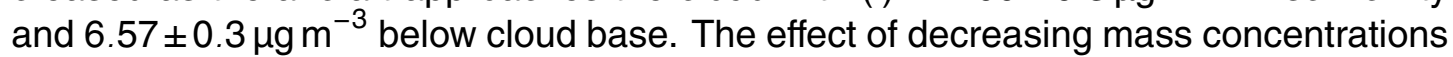
was even more pronounced during the afternoon flight (RF52), probably due to an increased wash out below the cloud. Indeed, the averaged mass concentrations during 10 RF52 are about $12.08 \mathrm{~g} \mathrm{~m}^{-3}$ in sc-vicinity and about $5.12 \pm 0.2 \mu \mathrm{g} \mathrm{m}^{-3}$ below cloud base (both measurements were performed at similar altitudes). Associated observations with a mesoscale simulation study demonstrate in a companion paper (Puygrenier et al., 2012), that the precipitation rates associated with this particular stratocumulus system were similar during the whole day. The differences in below-cloud mass concentration decreases ( 25 and $58 \%$ of aerosol mass during the RF51 and RF52, respectively) can then be explained by the duration of precipitation when comparing morning and afternoon flights. Wash out is expected to be more important for the afternoon flight since the airmass has been exposed to the system for a longer time.

In the free troposphere, the mass concentrations observed above the cloud layer are 20 low $\left(<1.16\right.$ and $<2.62 \mu^{-3} \mathrm{~m}^{-3}$ during the morning and the afternoon flights, respectively). As described before, the layer immediately above the cloud layer corresponds to the inversion layer. Thus, the low mass concentration values and the presence of finer particles above the cloud layer seem to be due to the entrainment of dry air in the cloud layer which trapped activated particles in cloud droplets and dilution of the aerosol concentration. Moreover, the decreasing aerosol mass concentrations between sc-vicinity and above cloud segments for both research flights are consistent with previous airborne observations (Hoppel et al., 1994).

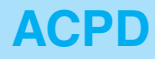

11, 33229-33271, 2011

\section{Impact of cloud processes on aerosol particle properties}

S. Crumeyrolle et al.

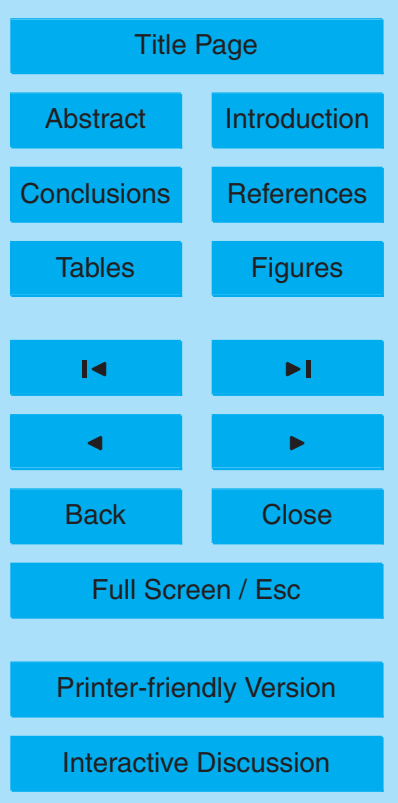




\subsection{2 "In cloud" measurements}

To investigate the characteristics of aerosol particle activation into cloud droplets, cToFAMS analyses of the aerosol material incorporated in cloud elements were performed. To study the aerosol incorporated in cloud droplets, the CVI sampling technology was

5 utilised. The CVI (Ogren et al., 1985) inlet has been designed to exclusively collect cloud elements (cloud droplets and ice crystals), while rejecting interstitial aerosol particles. After sampling, the individual hydrometeors are evaporated, thus extracting the residual material from the liquid phase. Subsequently the chemical composition of residual aerosol particles that were incorporated in the cloud droplets can be analyzed.

The average mass concentrations of aerosol particulate matter incorporated in the liquid phase of the stratocumulus cloud layer were found to be $3.92 \pm 1.09 \mu \mathrm{g} \mathrm{m}^{-3}$ and $2.78 \pm 1.15 \mathrm{\mu g} \mathrm{m}^{-3}$ (one standard deviation) during the morning and the afternoon flights, respectively. A very rough estimation of the activation diameter could be inferred from the aerosol particle size distributions measured in the vicinity of the cloud in the boundary layer, an assumed particle density of $1.8 \mathrm{~g} \mathrm{~cm}^{-3}$, and mass concentrations measured downstream the CVI inlet. The above values of 3.92 and $2.78 \mathrm{\mu g} \mathrm{m}^{-3}$ would lead to mean diameters of activated particles of $166 \mathrm{~nm}$ for the morning flight and of $233 \mathrm{~nm}$ for the afternoon flight. These activation diameters are larger than the Hoppel minimum observed in Fig. 5 may be due to the limits that are given by converting mass-based into numbers-based measurements. Additionally, the losses of particulate matter in the CVI inlet would decrease the in-cloud mass concentration and thus increase the activation diameter estimation.

\subsection{Chemical composition}

\subsection{1 "Cloud-free" measurements}

25 Averages of the fractional chemical composition of aerosol particles measured with the cToF-AMS for all flight segments are presented in Fig. 7 for the morning flight

\section{Impact of cloud processes on aerosol particle properties}

S. Crumeyrolle et al.

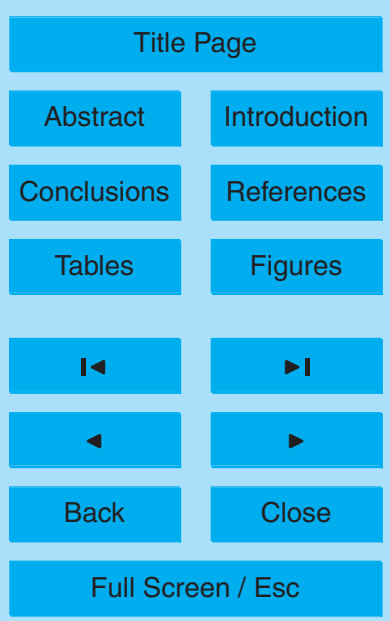

Printer-friendly Version

Interactive Discussion 
(RF51) and in Fig. 8 for the afternoon flight (RF52), respectively. In both figures, the top panel corresponds to the relative chemical composition of measurements in the free troposphere (corresponding to altitudes above the cloud top, namely beyond the cloud and in sc-vicinity), whereas the bottom figure corresponds to measurements in 5 the boundary layer (corresponding to below-cloud and sc-vicinity altitudes). For both layers, the exact measurement positions of sc-vicinity and below/above cloud segments are colour coded in the figures.

During the morning flight (RF51) in the FT, the fraction of organic aerosol material decreased with decreasing distance to the cloud (comparison between sc-vicinity and above/below cloud layer periods), while the fractions of sulfate and ammonium became more important. The low fraction of organic components above the cloud system may be related to the change of air mass types, as shown with the equivalent potential temperatures, and may be supported by the entrainment of dry air into the cloud layer. In general, the fraction of sulfate species in the aerosol is dominant ( $>45 \%$ ) except 15 to sulphate (anthropogenic Significant amounts of sulfate aerosol can form via aqueous-phase reactions in cloud droplets (Kerminen and Wexler, 1995; Hegg and Hobbs, 1982; Seigneur and Saxena, 1988; Joos and Baltensperger, 1991; Pandis et al., 1992), leading to higher sulfate concentrations in the residual particles of cloud droplets.

In comparison to the morning flight, in the afternoon the aerosol chemical composition shows significant differences. For example, the mass concentration of nonrefractory aerosol material in the sc-vicinity segment in the FT was 2.6 times lower during the afternoon flight; yet in the $\mathrm{BL}$, it was 1.3 times higher compared to the morn25 ing flight (Fig. 6).

Below the cloud layer, the organic and sulfate relative fractions, in the morning as well as in the afternoon, are clearly different from the relative fractions observed within sc-vicinity segments of corresponding altitudes. That is to say that below cloud the relative fractions of organics are small $(<15 \%)$, while the fractions of ammonium and

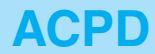

11, 33229-33271, 2011

\section{Impact of cloud processes on aerosol particle properties}

S. Crumeyrolle et al.

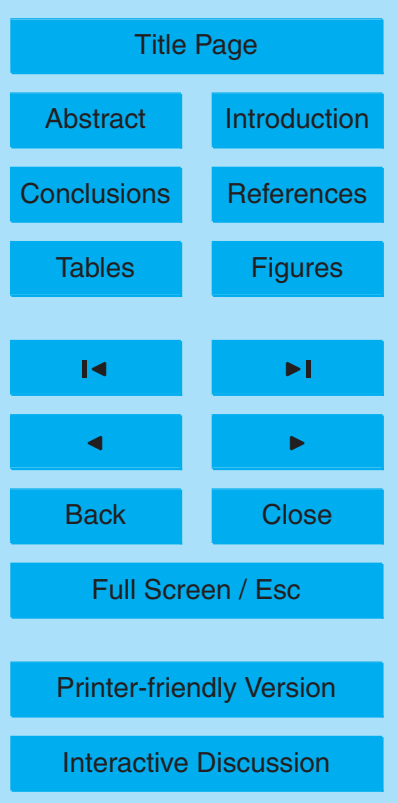


sulfate are high (Figs. 7 and 8), as compared to sc-vicinity. The change in composition can be due to the cloud processing of some of the remaining particles after drizzle evaporation, leading to high fractions of sulfate compared to organics.

\subsection{2 "In cloud" measurements}

5 The average fractional contribution of cloud residual aerosol chemical compounds for each in-cloud flight segment (700-1000 m altitude), are presented (a) in Fig. 9 for the morning and (b) in Fig. 10 for the afternoon flight, respectively. More than $68 \%$ of the mass concentration of non-refractory aerosol is composed of sulfate and organic components for all samples. The third most important compound is nitrate with relative 10 abundance of more than $8 \%$.

A comparison of the chemical composition of the total non-refractory particulate matter with the material incorporated in the liquid phase yields some interesting results (Table 4). The sulfate fractions, observed during "in-cloud" conditions, are 44 and $51 \%$ during the morning and the afternoon flight, respectively. Moreover, the absolute concentration of sulfate, during the afternoon flight, is two times larger during the sc-vicinity period in the $\mathrm{BL}\left(2.67 \pm 0.8 \mu \mathrm{g} \mathrm{cm}^{-3}\right)$ than during in cloud period $\left(1.45 \pm 0.58 \mu \mathrm{g} \mathrm{cm}^{-3}\right)$. The ratio of "in-cloud" concentration to "vicinity" concentration is a measure of yields the Efficiency of Activation and in-cloud Production (EAP). The sulfate EAP is low (24\%) compared to measurements shown in the literature (Hinds, 1998; Vocourt, 2002; Sell20 egri et al., 2003), which is likely due to losses in the CVI inlet.

The cloud residual concentrations of nitrate compounds $\left(0.55 \pm 0.10 \mu \mathrm{g} \mathrm{cm}^{-3}\right)$ are slightly larger than those measured within sc-vicinity segments in the BL $(0.32 \pm$ $0.05 \mathrm{\mu g} \mathrm{cm}^{-3}$ ) during the morning flight. The higher nitrate concentrations that are found in cloud residual as compared to sc-vicinity period in the BL suggest that some

nitrate is also produced in cloud droplets. If we hypothesise that nitrate is activated as efficiently as sulfate, then the excess, compared to sulfate, of nitrate in cloud production could be estimated at a minimum of $0.477 \mu_{\mathrm{g} \mathrm{cm}}^{-3}$. This in-cloud production of nitrate is thus corresponding to a large part ( $86 \%$ ) of the in-cloud mass concentration.
$11,33229-33271,2011$

\section{Impact of cloud processes on aerosol particle properties}

S. Crumeyrolle et al.

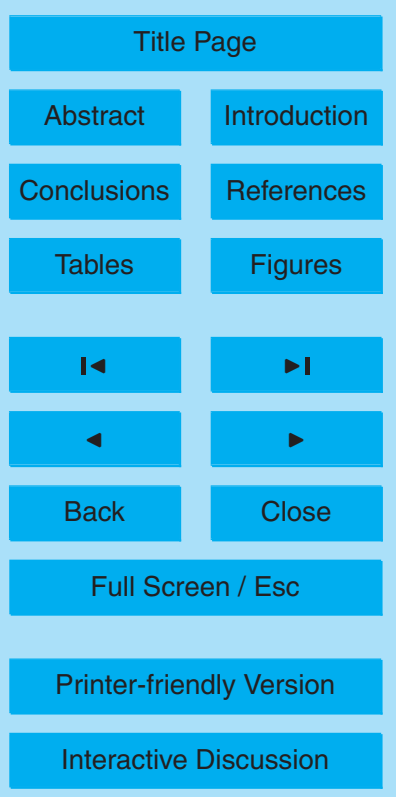

Interactive Discussion 
To determine whether the nitrate is produced in clouds as ammonium nitrate, the same reasoning has been applied to the ammonium concentration. The in-cloud production of ammonium is about $0.281 \mathrm{\mu g} \mathrm{cm}^{-3}$ (57\% of the in-cloud mass concentration) corresponding to $0.016 \mathrm{~mol}$. Thus, the in-cloud production of nitrate $(0.008 \mathrm{~mol})$ could be 5 entirely emitted as ammonium nitrate.

The organics absolute mass concentrations are higher in the dry phase $(3.355 \pm$ $0.14 \mu \mathrm{g} \mathrm{cm}^{-3}$ during the morning flight and $1.820 \pm 0.3 \mu \mathrm{g} \mathrm{cm}^{-3}$ during the afternoon flight) than in the liquid phase $\left(0.938 \pm 0.4 \mathrm{\mu g} \mathrm{cm}^{-3}\right.$ during the morning flight and $0.825 \pm$ $0.4 \mathrm{~g} \mathrm{~cm}^{-3}$ during the afternoon flight). Similarly to the nitrate, the organics efficiency 10 of activation and in-cloud production should be at most the same as for sulfate. The in-cloud production of organics is estimated at $0.124 \mu \mathrm{g} \mathrm{cm}^{-3}(13 \%$ of the total mass concentration).

The morning and afternoon flights comparison highlights different tendencies (Table 4). Assuming that the activation efficiency for each compound is the same during 15 both flights (i.e. at most $24 \%$ ), the in-cloud production of organic and sulfate is larger (by a factor of 4 for the organics) in the afternoon while the in-cloud production of nitrate and ammonium is similar. However, it appears to be quite speculative as we can not quantify the aerosol activation process for respective measurement.

Another major difference of absolute and relative concentrations is observed for chloride, as we compare cloud-free and in-cloud concentrations. Indeed, during scvicinity periods, the chloride fraction remains on average smaller than $1 \%$ (morning: $0.100 \pm 0.06 \mu \mathrm{g} \mathrm{cm}^{-3}$, afternoon: $0.020 \pm 0.01 \mu \mathrm{g} \mathrm{cm}^{-3}$ ). During "in-cloud" periods, the chloride fractions are on average between $1-10 \%$ (morning: $0.233 \pm 0.1 \mathrm{\mu g} \mathrm{cm}^{-3}$, afternoon: $0.065 \pm 0.04 \mathrm{\mu g} \mathrm{cm}^{-3}$ ). Thus, the chloride fractions are larger in cloud residuals than in dry aerosol particles, suggesting that most of the chloride mass is found in the largest (thus potentially cloud forming) particles.

Although it cannot be proven, the assumption that salt aerosol and gaseous organicchloride species emitted from the sea surface, are present in the BL over the North Sea appears to be plausible. These species are per-se hardly or not detectable by

\section{Impact of cloud processes on aerosol particle properties}

S. Crumeyrolle et al.

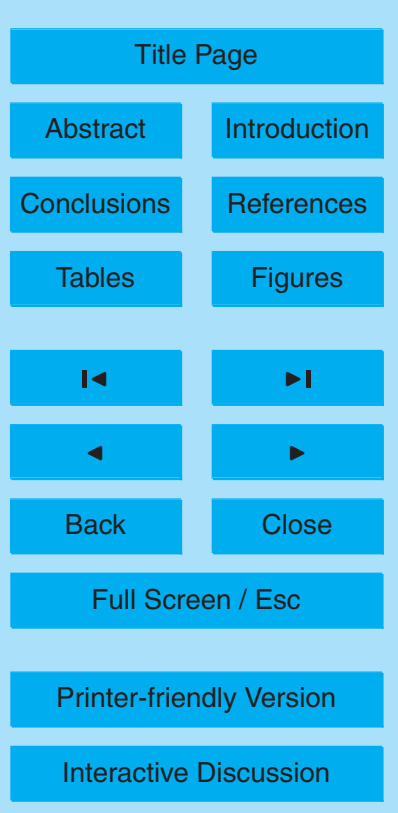


a cToF-AMS. Sodium chloride itself is an excellent CCN due to its strongly hygroscopic character and organic chloride compounds (e.g. methyl chloride) are most likely incorporated by cloud elements as well. It is also conceivable that in the cloud element residuals, e.g., inorganic chloride aerosol species such as hydrogen chloride $(\mathrm{HCl})$ or 5 ammonium chloride $\left(\mathrm{NH}_{4} \mathrm{Cl}\right)$ are present, or that complex organic chloride compounds are bonded to other vaporizable cloud element residuals.

\section{Summary and conclusions}

Within the frame of the EUCAARI intensive observation period, size distributions, mass concentrations, and chemical composition of aerosol particles have been measured during two research flights in order to study the aerosol-cloud interactions within an extended stratiform cloud system. On 15 May 2008, a stratocumulus cloud system formed over the North Sea, between Rotterdam (Netherlands) and Newcastle (UK). The ATR-42 performed two flights with an outgoing flight during the morning (RF51) and a return flight during the afternoon (RF52). In order to characterize the evolution vicinity segments to below/above as well as in cloud segments. Figures 10 and 11 summarise the measured mass concentrations as well as the chemical composition of particles observed during sc-vicinity, below/above stratocumulus layer, as well as incloud for research flights RF51 and RF52, respectively. The analysis of thermodynamic data highlights the presence of two distinct layers between 0-600 $\mathrm{m}$ (corresponding to the boundary layer) and 600-1200 $\mathrm{m}$ (corresponding to the free troposphere explored by the ATR-42 during the two flights). The analysis of wind directions observed during the morning and the afternoon flights reveals that observed air masses are originating from European continental sources.

25 The number size distributions show that Aitken $\left(D_{\mathrm{p}}<0.1 \mu \mathrm{m}\right)$ and accumulation $\left(0.1<D_{\mathrm{p}}<0.5 \mu \mathrm{m}\right)$ modes were present in both layers. The presence of particles from a nucleation mode $\left(D_{\mathrm{p}}<0.02 \mu \mathrm{m}\right)$ was also observed below the cloud layer during the

\section{1, 33229-33271, 2011}

\section{Impact of cloud processes on aerosol particle properties}

S. Crumeyrolle et al.

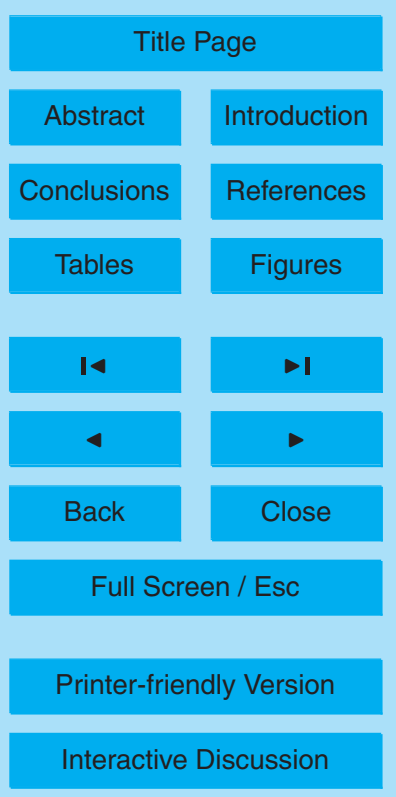


afternoon flight. The averaged size distributions observed below the cloud layer highlight a pronounced minimum between the two principal modes, known as the "Hoppel minimum" (Hoppel et al., 1994), of the bimodal aerosol size distribution observed during stratocumulus-vicinity period. Since below cloud base, drizzle precipitation had 5 been observed, we can conclude that this pronounced bimodal shape is due to cloud processes (activation, addition of mass to cloud droplets, subsequent evaporation and partly wash out of particles by precipitation).

Moreover, the concentration of particles in the accumulation mode size range decreases above and below the cloud layer as compared to sc-vicinity air masses, con10 sistent with the simultaneous decrease of mass concentrations shown in Figs. 10 and 11. The loss of particulate mass above the cloud is related to entrainment of dry air into the cloud layer and the loss below the cloud is due to precipitation wash out.

Finally, Figs. 10 and 11 highlight a strong dependence of the aerosol chemical composition on the observation location (sc-vicinity or below/above cloud). The fraction of nitrate compounds increases in the cloud residual phase, while the fraction of sulfate decreases. Assuming that the activation efficiency is similar for organics, nitrates and sulphate, the in-cloud production efficiency was estimated. The nitrate in-cloud production is estimated at $90 \%$ of the activated mass concentration on average, while the organic in-cloud production is about $13 \%$ in the morning and $52 \%$ in the afternoon. In order to improve our knowledge on complex aerosol-cloud processes, this case study could be used by the modeling community as a reference for the conditions related to stratiform cloud.

Acknowledgements. This work has been partially funded by European Commission 6th Framework program project EUCAARI, contract no 036833-2 (EUCAARI), and by the French National Research Agency (ANR) under the AEROCLOUD program, contract no 06-BLAN-0209. Suzanne Crumeyrolle has been supported by CNRS fellowship (contract no. 167641). The authors wish to thank the SAFIRE (Service des Avions Franais Instruments pour la Recherche en Environnement) for preparing and delivering the research aircraft (ATR-42).

\section{ACPD}

11, 33229-33271, 2011

\section{Impact of cloud processes on aerosol particle properties}

S. Crumeyrolle et al.

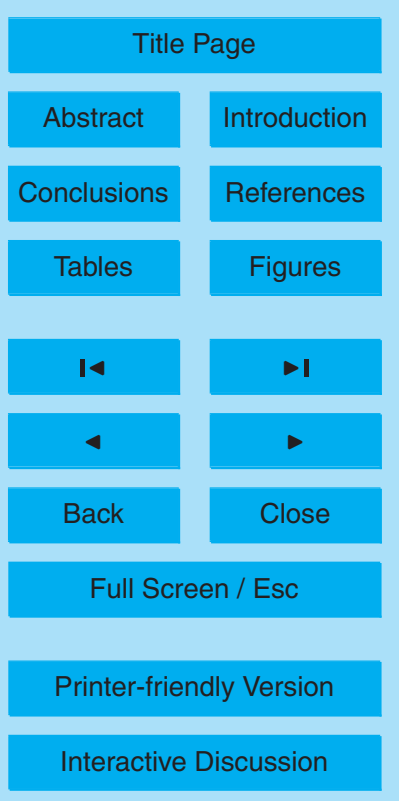


The publication of this article is financed by CNRS-INSU.

\section{References}

Andrejczuk, M., Grabowski, W. W., Reisner, J., and Gadian, A.: Cloud-aerosol interactions for boundary layer stratocumulus in the Lagrangian Cloud Model, J. Geophys. Res., 115, D22214, doi:10.1029/2010JD014248, 2010.

Bahreini, R., Dunlea, E. J., Matthew, B. M., Simons, C., Docherty, K. S., DeCarlo, P. F., Jimenez, J. L., Brock, C. A., and Middlebrook, A. M.: Design and operation of a pressure controlled inlet for airborne sampling with an aerodynamic aerosol Lens, Aerosol Sci. Tech., $10 \quad 42,6,465-471,2008$.

Bower, K. N., Choularton, T. W., Gallagher, M. W., Colvile, R. N., Wells, M., Beswick, K. M., Wiedensohler, A., Hansson, H.-C., Svenningsson, B., Swietlicki, E., Wendisch, M., Berner, A., Kruisz, C., Laj, P., Facchini, M. C., Fuzzi, S., Bizjak, M., Dollard, G., Jones, B., Acker, K., Wieprecht, W., Preiss, M., Sutton, M. A., Hargreaves, K. J., Storeton-West, R. L., Cape, J. N., and Arends, B. G.: Observation and modelling of the processing of aerosol by a hill cap cloud, Atmos. Environ., 31, 2527-2543, 1997.

Canagaratna, M. R., Jayne, J. T., Jimenez, J. L., Allan, J. D., Alfarra, M. R., Zhang, Q., Onasch, T. B., Drewnick, F., Coe, H., Middlebrook, A., Delia, A., Williams, L. R., Trimborn, A. M., Northway, M. J., DeCarlo, P. F., Kolb, C. E., Davidovits, P., and Worsnop, D. R.: Chemical and microphysical characterization of ambient aerosols with the aerodyne aerosol mass spectrometer, Mass Spectrom. Rev., 26, 185-222, 2007.

Chuang, C., Penner, J., Taylor, K., Grossman, A., and Walton, J.: An assessment of the radiative effects of anthropogenic sulfate, J. Geophys. Res., 102(D3), 3761-3778, 1997.

Clarke, A., Eisele, F., Kapustin, V., Moore, K., Tanner, D., Mauldin, L., Litchy, M., Lienert, B.,

\section{ACPD}

\section{Impact of cloud processes on aerosol particle properties}

S. Crumeyrolle et al.

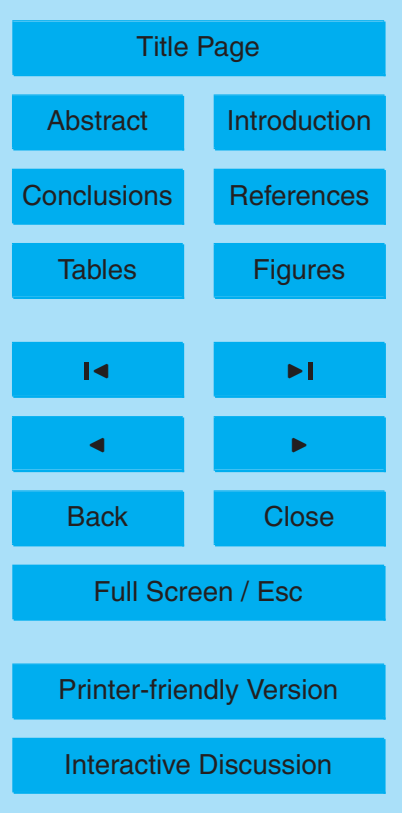


Carroll, M., and Albercook, G.: Nucleation in the equatorial free troposphere: favorable environments during PEM-Tropics, J. Geophys. Res., 104, 5735-5744, 1999.

Crumeyrolle, S., Gomes, L., Tulet, P., Matsuki, A., Schwarzenboeck, A., and Crahan, K.: Increase of the aerosol hygroscopicity by cloud processing in a mesoscale convective 5 system: a case study from the AMMA campaign, Atmos. Chem. Phys., 8, 6907-6924, doi:10.5194/acp-8-6907-2008, 2008.

Crumeyrolle, S., Manninen, H. E., Sellegri, K., Roberts, G., Gomes, L., Kulmala, M., Weigel, R., Laj, P., and Schwarzenboeck, A.: New particle formation events measured on board the ATR-42 aircraft during the EUCAARI campaign, Atmos. Chem. Phys., 10, 6721-6735, doi:10.5194/acp-10-6721-2010, 2010.

Cubison, M. J., Ervens, B., Feingold, G., Docherty, K. S., Ulbrich, I. M., Shields, L., Prather, K., Hering, S., and Jimenez, J. L.: The influence of chemical composition and mixing state of Los Angeles urban aerosol on CCN number and cloud properties, Atmos. Chem. Phys., 8 , 5649-5667, doi:10.5194/acp-8-5649-2008, 2008.

15 Drewnick, F., Hings, S. S., DeCarlo, P. F., Jayne, J. T., Gonin, M., Fuhrer, K., Weimer, S., Jimenez, J. L., Demerjian, K. L., Borrmann, S., and Worsnop, D. R.: A new Time-of-Flight Aerosol Mass Spectrometer (ToF-AMS) - instrument description and first field deployment, Aerosol Sci. Tech., 39, 637-658, 2005.

Feingold, G., Kreidenweis, S. M., Stevens, B., and Cotton, W. R.: Numerical simulations of stratocumulus processing of cloud condensation nuclei through collision-coalescence, J. Geophys. Res., 101, 21391-21402, 1996.

Fitzgerald, J., Martin, J. J., Hoppel, W. A., Frick, G. M., and Gelbard, J.: A one-dimensional sectional model to simulate multi-component aerosol dynamics in the marine boundary layer, 2, Modeling application, J. Geophys. Res., 103, 16103-16117, 1998.

George, I. J. and Abbatt, J. P. D.: Chemical evolution of secondary organic aerosol from $\mathrm{OH}-$ initiated heterogeneous oxidation, Atmos. Chem. Phys., 10, 5551-5563, doi:10.5194/acp10-5551-2010, 2010.

Harrison, R. G.: Cloud formation and the possible significance of charge for atmospheric condensation and ice nuclei, Space Sci. Rev., 94, 381-396, 2000.

so Hartmann, D., Ockert-Bell, M., and Michelsen, M.: The effect of cloud type on earth's energy balance: global analysis, J. Climate, 5, 1281-1304, 1992.

Haywood, J., Francis, P., Osborne, S., Glew, M., Loeb, N., Highwood, E., Tanré, D., Myhre, G., Formenti, P., and Hirst, E.: Radiative properties and direct radiative effect of Saharan dust 
measured by the C-130 aircraft during SHADE: 1. Solar spectrum, J. Geophys. Res., 108, 8577, doi:10.1029/2002JD002687, 2003.

Hegg, D. A. and Hobbs, P. V.: Measurement of sulfate production in natural clouds, Atmos. Environ., 16, 2663-2668, 1982.

5 Hinds, W. C.: Aerosol Technology: Properties, Behavior, and Measurement of Airborne Particles, 2nd edn., John Wiley, New York, 1998.

Hoppel, W. A., Frick, G. M., and Larson, R. E.: Effects on non-precipitating clouds on the aerosol size distribution in the marine boundary layer, Geophys. Res. Lett., 13, 125-128, 1986.

10 Hoppel, W. A., Frick, G. M., Fitzgerald, J. W., and Larson, R. E.: Marine boundary layer measurements of new particle formation and the effects nonprecipitating clouds have on aerosol size distribution, J. Geophys. Res., 99, 14443-14459, doi:10.1029/94JD00797, 1994.

IPCC: Intergovernmental Panel on Climate Change, ClimateChange 2007 - The Physical Science Basis: Contribution ofWorking Group I to the Fourth Assessment Report of the IPCC, Cambridge University Press, Cambridge, 2007.

Jiang, H., Feingold, G., and Cotton, W. R.: Simulations of aerosol-cloud-dynamical feedbacks resulting from entrainment of aerosol into the marine boundary layer during the Atlantic Stratocumulus Transition Experiment, J. Geophys. Res., 107, 4813, doi:10.1029/2001JD001502, 2002.

20 Joos, F. and Baltensperger, U.: A field study on chemistry, S(IV) oxidation rates and vertical transport during fog conditions, Atmos. Environ. A.-Gen., 25, 217-230, 1991.

Katrib, Y., Martin, S. T., Rudich, Y., Davidovits, P., Jayne, J. T., and Worsnop, D. R.: Density changes of aerosol particles as a result of chemical reaction, Atmos. Chem. Phys., 5, 275291, doi:10.5194/acp-5-275-2005, 2005.

Kerminen, V. M. and Wexler, A. S.: Growth laws for atmospheric aerosol particles: an examination of the bimodality of the accumulation mode, Atmos. Environ., 29, 3263-3275, 1995.

Köhler, H.: The nucleus in and the growth of hygroscopic droplets, T. Faraday Soc., 32(2), 1152-1161, 1936.

Kulmala, M., Asmi, A., Lappalainen, H. K., Carslaw, K. S., Pöschl, U., Baltensperger, U., Hov, Ø., Brenquier, J.-L., Pandis, S. N., Facchini, M. C., Hansson, H.-C., Wiedensohler, A., and O'Dowd, C. D.: Introduction: European Integrated Project on Aerosol Cloud Climate and Air Quality interactions (EUCAARI) - integrating aerosol research from nano to global scales, Atmos. Chem. Phys., 9, 2825-2841, doi:10.5194/acp-9-2825-2009, 2009.

\section{Impact of cloud processes on aerosol particle properties}

S. Crumeyrolle et al.

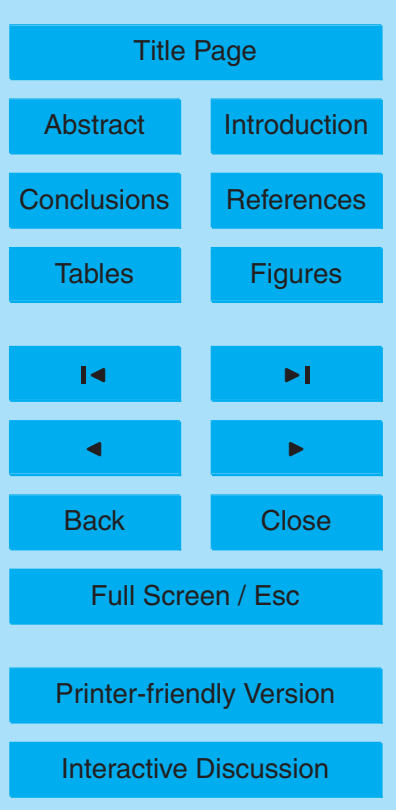


Kulmala, M., Asmi, A., Lappalainen, H. K., Baltensperger, U., Brenguier, J.-L., Facchini, M. C., Hansson, H.-C., Hov, Ø., O'Dowd, C. D., Pöschl, U., Wiedensohler, A., Boers, R., Boucher, O., de Leeuw, G., Denier van den Gon, H., Feichter, J., Krejci, R., Laj, P., Lihavainen, H., Lohmann, U., McFiggans, G., Mentel, T., Pilinis, C., Riipinen, I., Schulz, M., Stohl, A., Swietlicki, E., Vignati, E., Amann, M., Amann, M., Alves, C., Arabas, S., Artaxo, P., Beddows, D. C. S., Bergström, R., Beukes, J. P., Bilde, M., Burkhart, J. F., Canonaco, F., Clegg, S., Coe, H., Crumeyrolle, S., D’Anna, B., Decesari, S., Gilardoni, S., Fischer, M., Fjraa, A. M., Fountoukis, C., George, C., Gomes, L., Halloran, P., Hamburger, T., Harrison, R. M., Herrmann, H., Hoffmann, T., Hoose, C., Hu, M., Hrrak, U., linuma, Y., Iversen, T., Josipovic, M., Kanakidou, M., Kiendler-Scharr, A., Kirkevåg, A., Kiss, G., Klimont, Z., Kolmonen, P., Komppula, M., Kristjánsson, J.-E., Laakso, L., Laaksonen, A., Labonnote, L., Lanz, V. A., Lehtinen, K. E. J., Makkonen, R., McMeeking, G., Merikanto, J., Minikin, A., Mirme, S., Morgan, W. T., Nemitz, E., O’Donnell, D., Panwar, T. S., Pawlowska, H., Petzold, A., Pienaar, J. J., Pio, C., Plass-Duelmer, C., Prévôt, A. S. H., Pryor, S., Reddington, C. L., Roberts, G., Rosenfeld, D., Schwarz, J., Seland, Ø., Sellegri, K., Shen, X. J., Shiraiwa, M., Siebert, H., Sierau, B., Simpson, D., Sun, J. Y., Topping, D., Tunved, P., Vaattovaara, P., Vakkari, V., Veefkind, J. P., Visschedijk, A., Vuollekoski, H., Vuolo, R., Wehner, B., Wildt, J., Woodward, S., Worsnop, D. R., van Zadelhoff, G.-J., Zardini, A. A., Zhang, K., van Zyl, P. G., Kerminen, V.-M., Carslaw, K. S., and Pandis, S. N.: General overview: European Integrated project on Aerosol Cloud Climate and Air Quality interactions (EUCAARI) - integrating aerosol research from nano to global scales, Atmos. Chem. Phys. Discuss., 11, 17941-18160, doi:10.5194/acpd-11-17941-2011, 2011.

Levin, Z., Ganor, E., and Gladstein, V.: The effects of desert particles coated with sulfate on rain formation in the eastern mediterranean, J. Appl. Meteorol., 35, 1511-1523, 1996.

Liu, P. S. K., Deng, R., Smith, K. A., Williams, L. R., Jayne, J. T., Canagaratna, M. R., Moored, K., Onasch, T. B., Worsnop, D. R., and Deshler, T.: Transmission efficiency of an aerodynamic focusing lens system: comparison of model calculations and laboratory measurements for the aerodyne aerosol mass spectrometer, Aerosol Sci. Tech., 41, 721-733, 2007.

30 Lohmann, U., Broekhuizen, K., Leaitch, R., Shantz, N., and Abbatt, J.: How efficient is cloud droplet formation of organic aerosols?, Geophys. Res. Lett., 31, L05108, doi:10.1029/2003GL018 999, 2004.

Matsuki, A., Schwarzenboeck, A., Venzac, H., Laj, P., Crumeyrolle, S., and Gomes, L.: Cloud 
processing of mineral dust: direct comparison of cloud residual and clear sky particles during AMMA aircraft campaign in summer 2006, Atmos. Chem. Phys., 10, 1057-1069, doi:10.5194/acp-10-1057-2010, 2010.

McNaughton, C. S., Clarke, A. D., Howell, S. G., Pinkerton, M., Anderson, B., Thornhill, L., 5 Hudgins, C., Winstead, E., Dibb, J. E., Sceuer, E., and Maring, H.: Results from the DC-8 Inlet Characterization Experiment (DICE): airborne versus surface sampling of mineral dust and sea salt aerosols, Aerosol Sci. Tech., 41, 136-159, 2007.

Murphy, D. M., Thomson, D. S., and Mahoney, M. J.: In situ measurements of organics, meteoritic material, mercury, and other elements in aerosols at 5 to 19 kilometers, Science, 282, 1664-1669, 1998.

Nenes, A. and Seinfeld, J. H.: Parameterization of cloud droplet formation in global climate models, J. Geophys. Res., 108(D14), 4415, doi:10.1029/2002JD002911, 2003.

Nenes, A., Ghan, S. J., Abdul-Razzak, H., Chuang, P. Y., and Seinfeld, J. H.: Kinetic limitations on cloud droplet formation and impact on cloud albedo, Tellus B, 53, 133-149, 2001.

15 Ogren, J. A., Heintzenberg, J., and Charlson, R. J.: In-situ sampling of clouds with a droplet to aerosol converter, Geophys. Res. Lett., 12, 121-124, 1985.

Pandis, S. N., Seinfeld, J. H., and Pilinis, C.: Heterogeneous sulfate production in an urban fog, Atmos. Environ. A-Gen., 26, 2509-2522, 1992.

Protat, A., Pelon, J., Testud, J., Grand, N., Delville, P., Laborie, P., Vinson, J.-P., Bouniol, D., Bruneau, D., Chepfer, H., Delanoë, J., Haeffelin, M., Noël, V., and Tinel, C.: Le projet RALI : combinaison d'un radar nuage et d'un lidar pour l'étude des nuages faiblement précipitants, La Météorologie, 47, 23-33, 2004.

Puygrenier V., Thouron, O., Roberts, G., Gomes, L., andBrenguier, J. L.: LES simulation of a stratocumulus diurnal cycle observed during EUCAARI, to be submitted, 2012.

Reutter, P., Su, H., Trentmann, J., Simmel, M., Rose, D., Gunthe, S. S., Wernli, H., Andreae, M. O., and Pöschl, U.: Aerosol- and updraft-limited regimes of cloud droplet formation: influence of particle number, size and hygroscopicity on the activation of cloud condensation nuclei (CCN), Atmos. Chem. Phys., 9, 7067-7080, doi:10.5194/acp-9-7067-2009, 2009.

Roberts, G. C., Andreae, M. O., Zhou, J., and Artaxo, P.: Cloud condensation nuclei in the Amazon Basin: Marine conditions over a continent?, Geophys. Res. Lett., 28(14), 28072810, 2001.

Roberts, G. C., Day, D. A., Russell, L. M., Dunlea, E. J., Jimenez, J. L., Tomlinson, J. M., Collins, D. R., Shinozuka, Y., and Clarke, A. D.: Characterization of particle cloud droplet
ACPD

11, 33229-33271, 2011

\section{Impact of cloud \\ processes on aerosol particle properties}

S. Crumeyrolle et al.

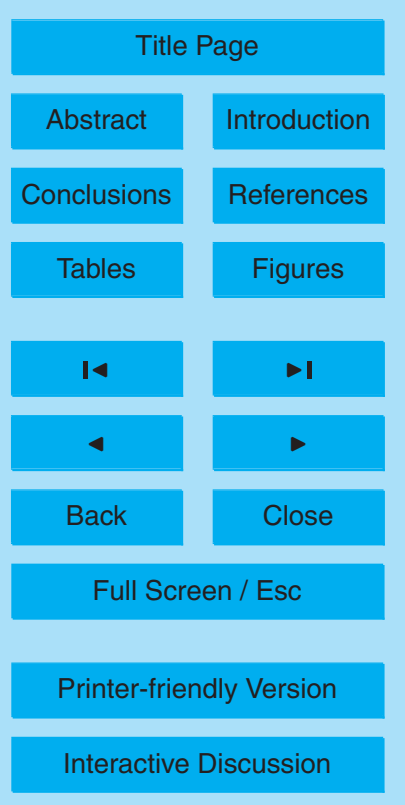


activity and composition in the free troposphere and the boundary layer during INTEX-B, Atmos. Chem. Phys., 10, 6627-6644, doi:10.5194/acp-10-6627-2010, 2010.

Schwarzenboeck, A., Heintzenberg, J., and Mertes, M.: Incorporation of aerosol particles between 25 and $850 \mathrm{~nm}$ into cloud elements: measurements with a new complementary sam5 pling system, Atmos. Res., 52, 241-260, 2000.

Seigneur, C. and Saxena, P.: A theoretical investigation of sulfate formation in clouds, Atmos. Environ., 22, 101-115, 1988.

Sellegri, K., Laj, P., Dupuy, R., Legrand, M., Preunkert, S., Putaud, J.-P., and Cachier, H.: Sizedependent scavenging efficiencies of multi-component atmospheric aerosols in clouds, J.

10 Geophys. Res., 108(D11), 4334-4349, doi:10.1029/2002JD002749, 2003.

Slowik, J. G., Stainken, K., Davidovits, P., Williams, L. R., Jayne, J., Kolb, C. E., Worsnop, D., Rudich, Y., DeCarlo, P., and Jimenez, J.: Particle morphology and density characterization by combined mobility and aerodynamic diameter measurements. Part 2: Application to combustion generated soot particles as a function of fuel equivalence ratio, Aerosol Sci. Tech., 28(12), 1206-1222, 2004.

Stohl, A., Hittenberger, M., and Wotawa, G.: Validation of the Lagrangian particle dispersion model FLEXPART against large scale tracer experiment data, Atmos. Environ., 24, 42454264, 1998.

Stohl, A., Forster, C., Frank, A., Seibert, P., and Wotawa, G.: Technical note: The Lagrangian particle dispersion model FLEXPART version 6.2, Atmos. Chem. Phys., 5, 2461-2474, doi:10.5194/acp-5-2461-2005, 2005.

Sullivan, R. C., Moore, M. J. K., Petters, M. D., Kreidenweis, S. M., Roberts, G. C., and Prather, K. A.: Effect of chemical mixing state on the hygroscopicity and cloud nucleation properties of calcium mineral dust particles, Atmos. Chem. Phys., 9, 3303-3316, doi:10.5194/acp-9-3303-2009, 2009.

Villani, P., Picard, D., Marchand, N., and Laj, P.: Design and Validation of a Volatility Tandem Differential Mobility Analyzer (VTDMA), Aerosol Sci. Tech., 41(10), 898-906, 2007.

Vocourt, V.: Etalonnage et Simulation numerique d'une Sonde a Impaction Virtuelle (CVI) dans le cadre de l'etude des proprietes physico-chimiques des particules nuageuses, Ph.D. thesis, 30 Blaise Pascal, Clermont Ferrand, 2002.

Wang, M., Ghan, S., Easter, R., Ovchinnikov, M., Liu, X., Kassianov, E., Qian, Y., Gustafson Jr., W. I., Larson, V. E., Schanen, D. P., Khairoutdinov, M., and Morrison, H.: The multi-scale aerosol-climate model PNNL-MMF: model description and evaluation, Geosci. Model Dev.,

\section{Impact of cloud processes on aerosol particle properties}

S. Crumeyrolle et al.

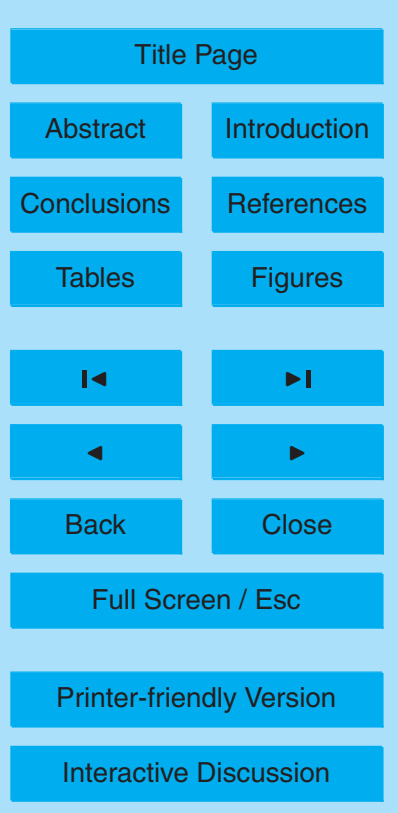


4, 137-168, doi:10.5194/gmd-4-137-2011, 2011.

Warren, S., Hahn, C., London, J., Chervin, R., and Jenne, R.: Global distribution of total cloud cover and cloud type amounts over the ocean. NCAR Tech. Note NCAR/TN-317_STR, 42 pp., 1988.

5 Weigel R., F. Drewnick, W. Morgan, J. Allan, S. Crumeyrolle, J. Schneider, H. Coe, H. Wernli, K. Kandler, P. Nedelec, J.-M. Pichon, A. Schwarzenbck, K. Sellegri, P. Laj; Central European pollution aerosol studied with an airborne Time-of-Flight Aerosol Mass Spectrometer during EUCAARI-IMPACT, May 2008, Atmos. Chem. Phys. Disc., to be submitted, 2012.

Wurzler, S., Reisin, T. G., and Levin, Z.: Modification of mineral dust particles by cloud processing and subsequent effects on drop size distributions, J. Geophys. Res., 105(D5), 45014512, 2000.

Yin, Y., Wurzler, S., Levin, Z., and Reisin, T. G.: Interactions of mineral dust particles and clouds: effects on precipitation and cloud optical properties, J. Geophys. Res., 107, 4724, doi:10.1029/2001JD001544, 2002.

Zhang, X., Smith, K. A., Worsnop, D. R., Jimenez, J. L., Jayne, J. T., Kolb, C. E., Morris, J., and Davidovits, P.: Numerical characterization of particle beam collimation: Part II Integrated aerodynamic lens-nozzle system, Aerosol Sci. Tech., 38, 6, 619-638, 2004.

\section{ACPD}

11, 33229-33271, 2011

\section{Impact of cloud processes on aerosol particle properties}

S. Crumeyrolle et al.

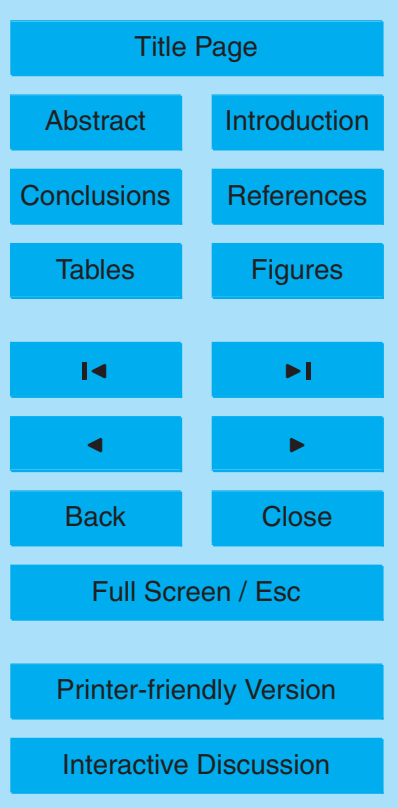




\section{ACPD}

11, 33229-33271, 2011

\section{Impact of cloud processes on aerosol particle properties}

Table 1. Flight parameters during selected periods of interest of research flight RF51.

\begin{tabular}{lcrcc}
\hline $\begin{array}{l}\text { Period } \\
\text { label }\end{array}$ & $\begin{array}{c}\text { Time interval } \\
\text { in hh:mm }\end{array}$ & $\begin{array}{r}\text { Altitude } \\
(\mathrm{m})\end{array}$ & $\begin{array}{c}\text { ATR-42 position } \\
\text { relative to the cloud }\end{array}$ & $\begin{array}{c}\theta_{\mathrm{e}} \\
\text { in K }\end{array}$ \\
\hline V1 & $07: 04-07: 07$ & 1130 & Sc-Vicinity & 236.5 \\
V2 & $07: 12-07: 14$ & 1130 & Sc-Vicinity & 229.5 \\
V3 & $07: 17-07: 21$ & 310 & Sc-Vicinity & 297.6 \\
V4 & $07: 21-07: 24$ & 325 & Sc-Vicinity & 296.5 \\
C1 & $08: 33-08: 36$ & 400 & Below Cloud & 297.8 \\
C2 & $08: 42-08: 44$ & 1180 & Above Cloud & 280.1 \\
C3 & $08: 50-08: 52$ & 355 & Below Cloud & 295.3 \\
C4 & $08: 58-09: 01$ & 1175 & Above Cloud & 273.0 \\
C5 & $09: 07-09: 13$ & 330 & Below Cloud & 299.4 \\
C6 & $09: 21-09: 25$ & 390 & Below Cloud & 296.9 \\
\hline
\end{tabular}

S. Crumeyrolle et al.

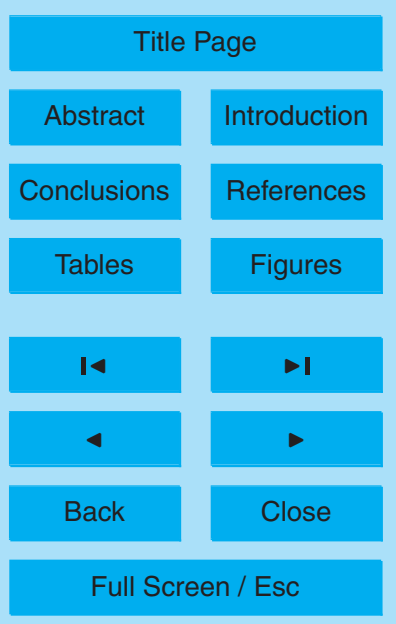

Printer-friendly Version

Interactive Discussion 


\section{ACPD}

$11,33229-33271,2011$

Table 2. Flight parameters during selected period of interest of research flight RF52.

\begin{tabular}{lcrcc}
\hline $\begin{array}{l}\text { Period } \\
\text { label }\end{array}$ & $\begin{array}{c}\text { Time interval } \\
\text { in hh:mm }\end{array}$ & $\begin{array}{r}\text { Altitude } \\
(\mathrm{m})\end{array}$ & $\begin{array}{c}\text { ATR-42 position } \\
\text { relative to the cloud }\end{array}$ & $\begin{array}{c}\theta_{\mathrm{e}} \\
\text { in K }\end{array}$ \\
\hline C1 & $11: 56-12: 08$ & 1500 & Above Cloud & 265.4 \\
C2 & $12: 27-12: 30$ & 1190 & Above Cloud & 279.6 \\
C3 & $12: 35-12: 38$ & 350 & Below Cloud & 297.7 \\
C4 & $12: 43-12: 45$ & 1170 & Above Cloud & 276.7 \\
C5 & $12: 51-12: 57$ & 360 & Below Cloud & 297.1 \\
C6 & $13: 01-13: 03$ & 1160 & Above Cloud & 272.6 \\
C7 & $13: 07-13: 12$ & 345 & Below Cloud & 299.5 \\
C8 & $13: 16-13: 19$ & 1180 & Above Cloud & 273.4 \\
C9 & $13: 22-13: 27$ & 395 & Below Cloud & 296.6 \\
C10 & $13: 34-13: 37$ & 1190 & Above Cloud & 272.9 \\
C11 & $13: 41-13: 44$ & 385 & Below Cloud & 300.0 \\
C12 & $13: 54-14: 01$ & 380 & Below Cloud & 300.6 \\
C13 & $14: 04-14: 08$ & 1100 & Above Cloud & 236.5 \\
C14 & $14: 11-14: 21$ & 370 & Below Cloud & 299.3 \\
V1 & $14: 17-14: 20$ & 375 & Sc-vicinity & 299.9 \\
V2 & $14: 23-14: 26$ & 1220 & Sc-vicinity & 239.3 \\
\hline
\end{tabular}

\section{Impact of cloud processes on aerosol particle properties}

S. Crumeyrolle et al.

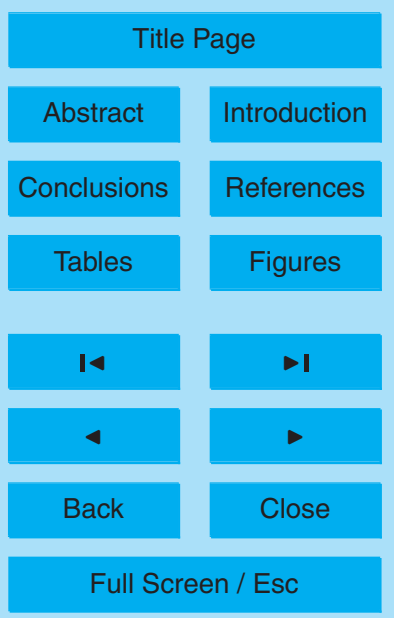

Printer-friendly Version

Interactive Discussion

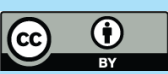


Table 3. Log-normal characteristics of the number size distributions shown in Fig. 5a. $C$ represents the concentration of the particle mode $\left(\mathrm{cm}^{-3}\right), \sigma$ the standard deviation of the number concentration $\left(\mathrm{cm}^{-3}\right)$, and $D_{\mathrm{p}}$ is the median diameter $(\mathrm{nm})$, NA stands for not applicable.

\begin{tabular}{cccccccc}
\hline & & \multicolumn{3}{c}{ Sc-Vicinity } & \multicolumn{3}{c}{ Below/Above Sc } \\
& & $C\left(\mathrm{~cm}^{-3}\right)$ & $\sigma$ & $D_{\mathrm{p}}(\mathrm{nm})$ & $C\left(\mathrm{~cm}^{-3}\right)$ & $\sigma$ & $D_{\mathrm{p}}(\mathrm{nm})$ \\
\hline \multirow{3}{*}{$\mathrm{BL}$} & Mode 1 & 104 & 1.3 & 35 & 275 & 1.29 & 38 \\
& Mode 2 & 224 & 1.24 & 47 & 33 & 1.14 & 120 \\
& Mode 3 & 443 & 1.44 & 176.9 & 223 & 1.32 & 223 \\
& Mode 1 & 392 & 1.34 & 48.3 & 316 & 1.16 & 26.9 \\
$\mathrm{FT}$ & Mode 2 & 451 & 1.4 & 146.6 & 107 & 2.0 & 88.3 \\
& Mode 3 & 96 & 1.47 & 234 & NA & NA & NA \\
\hline
\end{tabular}

\section{ACPD}

11, 33229-33271, 2011

\section{Impact of cloud processes on aerosol particle properties}

S. Crumeyrolle et al.

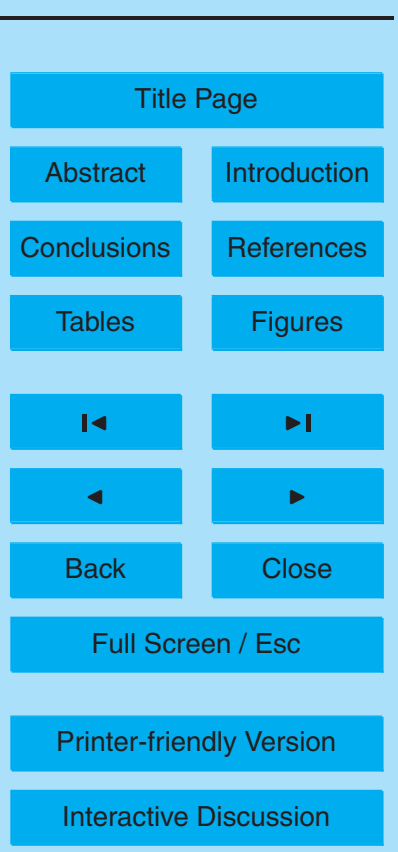




\section{ACPD}

11, 33229-33271, 2011

\section{Impact of cloud processes on aerosol particle properties}

Table 4. Log-normal characteristics of the number size distributions shown in Fig. $5 \mathrm{~b}$. $C$ represents the concentration of the particle mode $\left(\mathrm{cm}^{-3}\right), \sigma$ is the standard deviation of the number concentration $\left(\mathrm{cm}^{-3}\right)$ and $D_{\mathrm{p}}$ is the median diameter $(\mathrm{nm})$, NA stands for not applicable.

\begin{tabular}{|c|c|c|c|c|c|c|c|}
\hline & \multicolumn{3}{|c|}{ Sc-vicinity } & \multicolumn{3}{|c|}{ Below/Above Sc } \\
\hline & & $C\left(\mathrm{~cm}^{-3}\right)$ & $\sigma$ & $D_{\mathrm{p}}(\mathrm{nm})$ & $C\left(\mathrm{~cm}^{-3}\right)$ & $\sigma$ & $D_{\mathrm{p}}(\mathrm{nm})$ \\
\hline & Mode 1 & 490 & 1.34 & 53 & 130 & 1.25 & 21.2 \\
\hline BL & $\begin{array}{l}\text { Mode } 2 \\
\text { Mode } 3 \\
\text { Mode } 4\end{array}$ & $\begin{array}{l}444 \\
\text { NA } \\
\text { NA }\end{array}$ & $\begin{array}{l}1.45 \\
\text { NA } \\
\text { NA }\end{array}$ & $\begin{array}{c}173.5 \\
\text { NA } \\
\text { NA }\end{array}$ & $\begin{array}{c}246 \\
37 \\
183\end{array}$ & $\begin{array}{l}1.34 \\
1.19 \\
1.34\end{array}$ & $\begin{array}{c}45.7 \\
131 \\
242.2\end{array}$ \\
\hline FT & $\begin{array}{l}\text { Mode } 1 \\
\text { Mode } 2 \\
\text { Mode } 3\end{array}$ & $\begin{array}{l}89 \\
58 \\
62\end{array}$ & $\begin{array}{l}1.33 \\
1.31 \\
1.88\end{array}$ & $\begin{array}{c}46.3 \\
98.9 \\
137\end{array}$ & $\begin{array}{c}174 \\
59 \\
99\end{array}$ & $\begin{array}{l}1.41 \\
1.26 \\
1.41\end{array}$ & $\begin{array}{c}35.4 \\
109.4 \\
240\end{array}$ \\
\hline
\end{tabular}

Title Page

Abstract

Conclusions

Tables

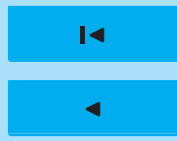

Back
Full Screen / Esc

Printer-friendly Version

Interactive Discussion 


\section{ACPD}

11, 33229-33271, 2011

\section{Impact of cloud processes on aerosol particle properties}

Table 5. Averaged mass concentration of organic, nitrate, sulphate, ammonium, chloride in the vicinity of the cloud and in the cloud during the morning (RF51) and the afternoon flight (RF52). In cloud production (IC production) is the estimated concentration of each component produced in the cloud (see text for more details).

\begin{tabular}{lllllll}
\hline & & $\begin{array}{l}\text { Organics } \\
\left(\mu \mathrm{g} \mathrm{m}^{-3}\right)\end{array}$ & $\begin{array}{l}\text { Nitrate } \\
\left(\mu \mathrm{g} \mathrm{m}^{-3}\right)\end{array}$ & $\begin{array}{l}\text { Sulphate } \\
\left(\mu \mathrm{g} \mathrm{m}^{-3}\right)\end{array}$ & $\begin{array}{l}\text { Ammonium } \\
\left(\mu \mathrm{m} \mathrm{m}^{-3}\right)\end{array}$ & $\begin{array}{l}\text { Chloride } \\
\left(\mu \mathrm{g} \mathrm{m}^{-3}\right)\end{array}$ \\
\hline \multirow{2}{*}{$\mathrm{RF}-51$} & Vicinity BL & 3.355 & 0.320 & 7.025 & 0.865 & 0.100 \\
& In cloud & 0.937 & 0.540 & 1.704 & 0.490 & 0.233 \\
& IC Production & 0.123 & 0.477 & 0 & 0.280 & 0.208 \\
& Vicinity BL & 1.624 & 0.070 & 2.074 & 0.658 & 0.027 \\
$\mathrm{RF}-52$ & In cloud & 0.817 & 0.268 & 1.371 & 0.251 & 0.071 \\
& IC Production & 0.423 & 0.251 & 0.868 & 0.092 & 0.065 \\
\hline
\end{tabular}

Title Page

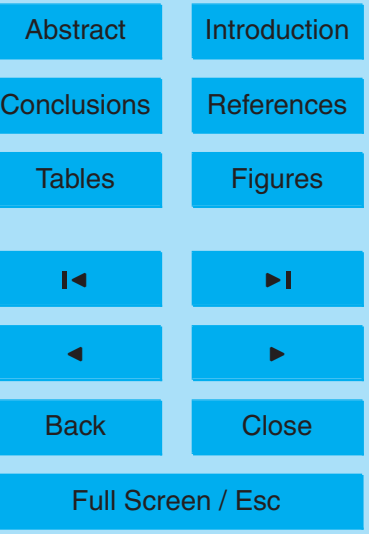

Printer-friendly Version

Interactive Discussion 


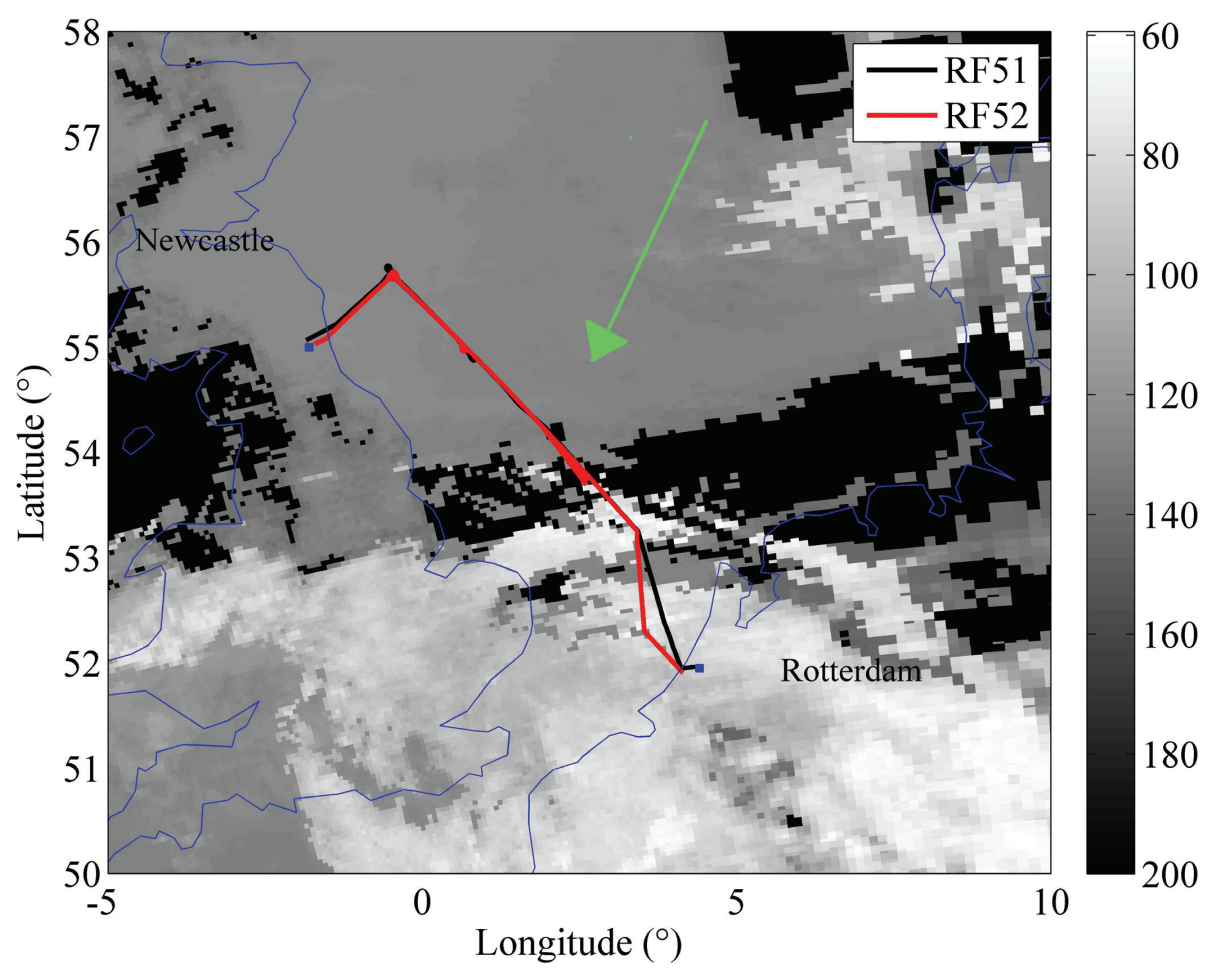

Fig. 1. Flight tracks of the two EUCAARI/IMPACT research flights (RF51 and RF52) performed on 15 May 2008 from Rotterdam (Netherlands) to Newcastle (UK) in the morning and subsequent return flight in the afternoon. The grayscale represents the brightness temperature from the MODIS-AQUA data for 15 May 2008 at 13:00. The green arrow illustrates the prevailing wind direction (see Figs. 3 and 4 for more details).

\section{ACPD}

$11,33229-33271,2011$

\section{Impact of cloud processes on aerosol particle properties}

S. Crumeyrolle et al.

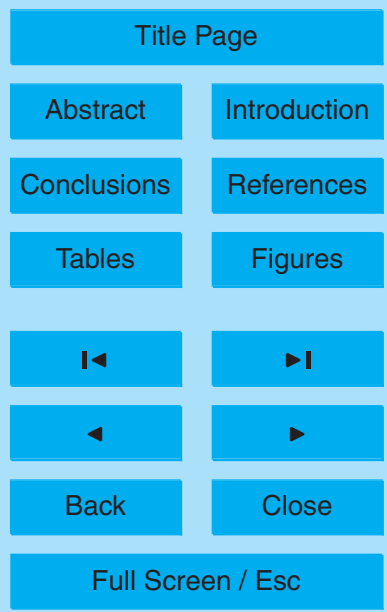

Printer-friendly Version

Interactive Discussion 


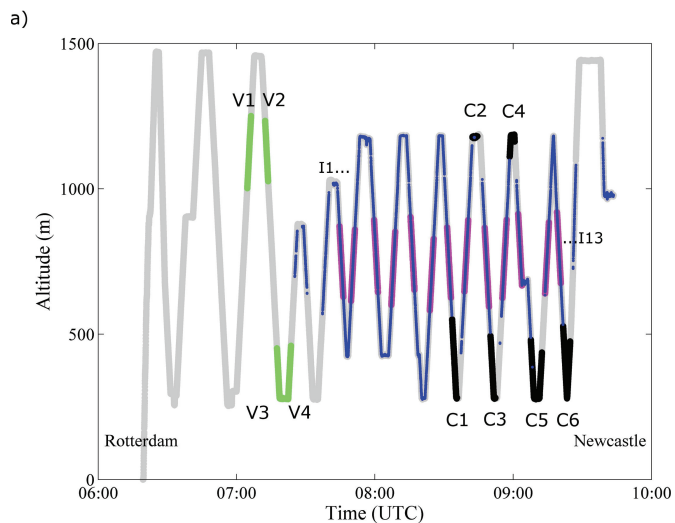

\section{ACPD}

11, 33229-33271, 2011

\section{Impact of cloud processes on aerosol particle properties}

S. Crumeyrolle et al.

b)

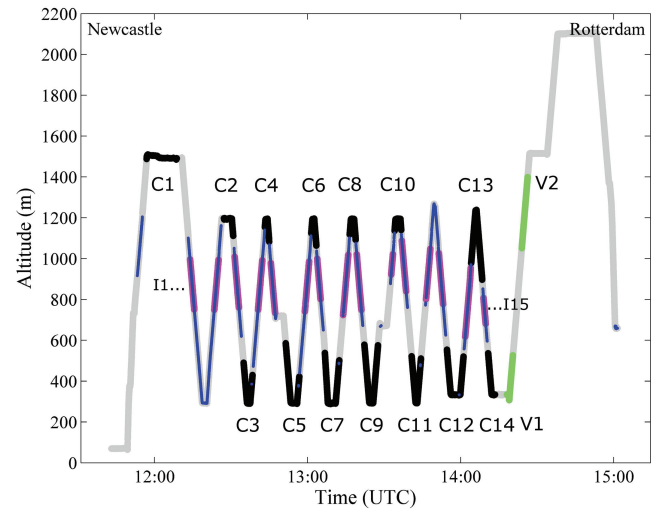

Title Page

Abstract Introduction

Conclusions References

Tables

Figures

14

4

Back

Close

Full Screen / Esc

Fig. 2. Flight pattern and altitudes as a function of time for RF51 and RF52 from (a) Rotterdam to Newcastle and (b) the return flight on 15 May 2008. The blue colour corresponds to the incloud periods. The measurements corresponding to in-cloud CVI measurements are illustrated by pink colours (I1-I13, and I1-I15, respectively). Green colour represents flight segments during sc-vicinity conditions, in the corresponding altitude range than measurements performed above/below (black) the stratocumulus cloud. 

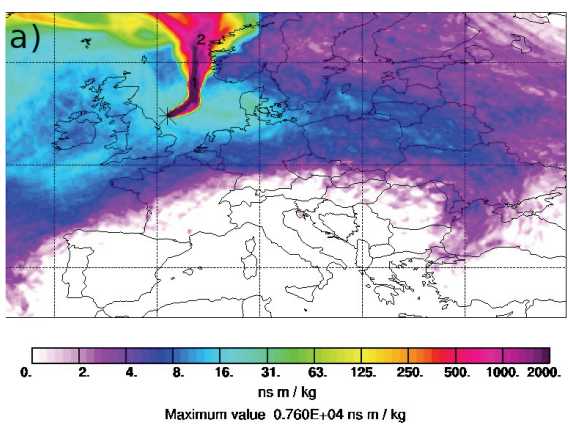

Maximum value $0.760 \mathrm{E}+04 \mathrm{~ns} \mathrm{~m} / \mathrm{kg}$
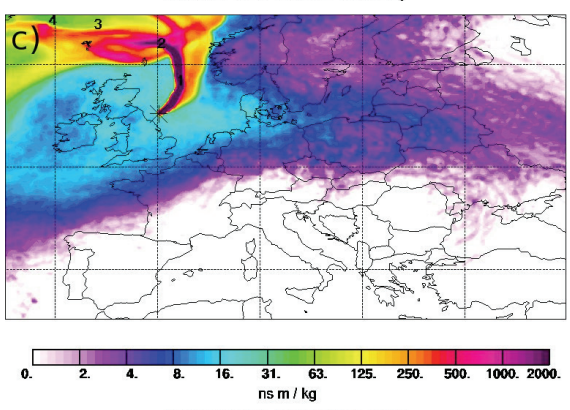

Maximum value $0.770 \mathrm{E}+04 \mathrm{~ns} \mathrm{~m} / \mathrm{kg}$
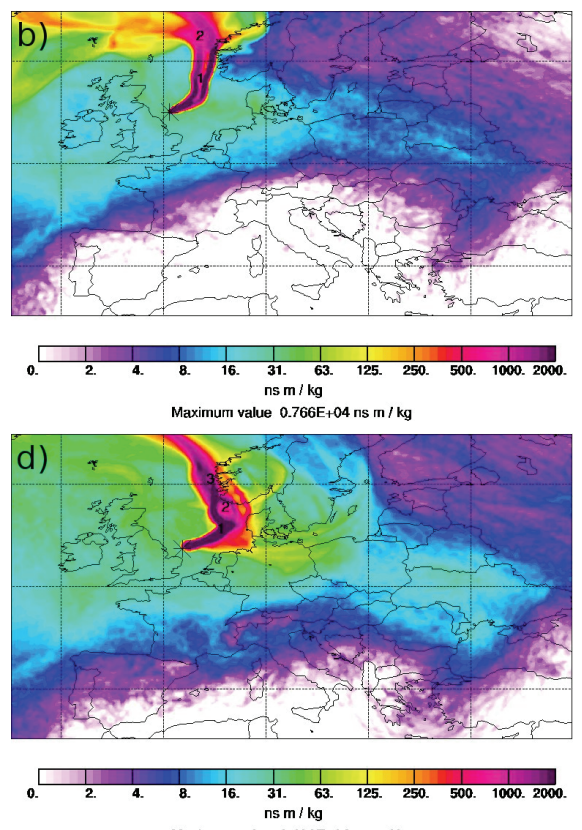

Maximum value $0.496 \mathrm{E}+04 \mathrm{~ns} \mathrm{~m} / \mathrm{kg}$

Fig. 3. Column integrated emission sensitivities obtained from the 3-day backward simulation with FLEXPART along the ATR-42 flight track on 15 May, 2008 at 07:29 UTC at the altitude of $403 \mathrm{~m} \mathrm{(a),} \mathrm{09:02} \mathrm{UTC} \mathrm{at} 901 \mathrm{~m}$ (b), 12:21 UTC at $349 \mathrm{~m}$ (c), and 14:08 UTC at $920 \mathrm{~m}$ (d). Numbers represent the days backward in time.

\section{ACPD}

11, 33229-33271, 2011

\section{Impact of cloud processes on aerosol particle properties}

S. Crumeyrolle et al.

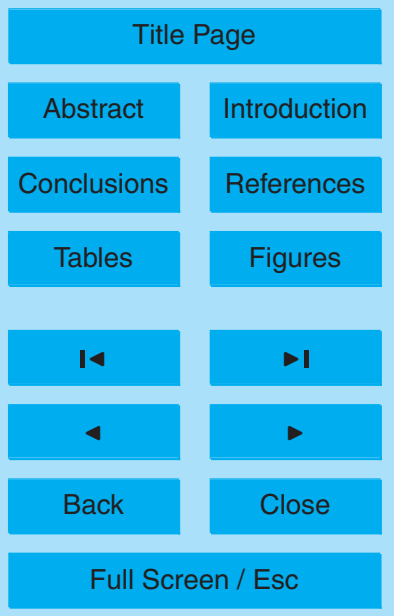

Printer-friendly Version

Interactive Discussion 

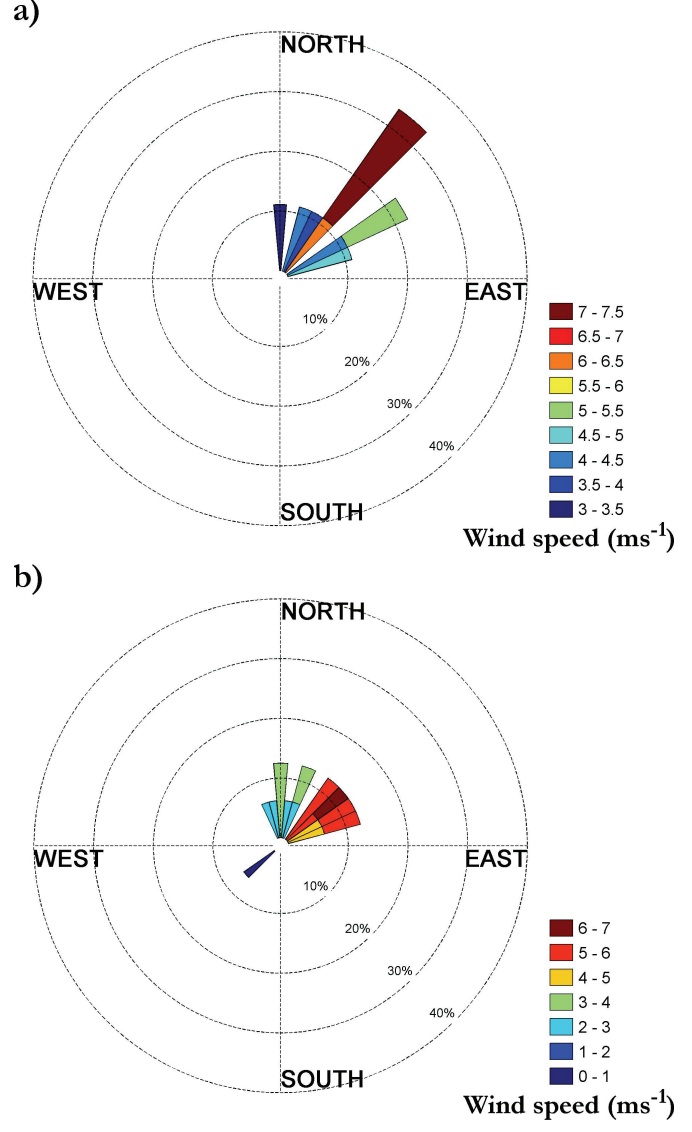

Fig. 4. Wind roses calculated for constant altitude legs for the morning flight (RF51, a) and the afternoon flight (RF52, b). The colorscale indicates wind speed (i.e. between 0 and $10 \mathrm{~m} \mathrm{~s}^{-1}$ ). The bar length correspond to the occurrence frequency of respective wind direction throughout each episode.

\section{ACPD}

$11,33229-33271,2011$

\section{Impact of cloud processes on aerosol particle properties}

S. Crumeyrolle et al.

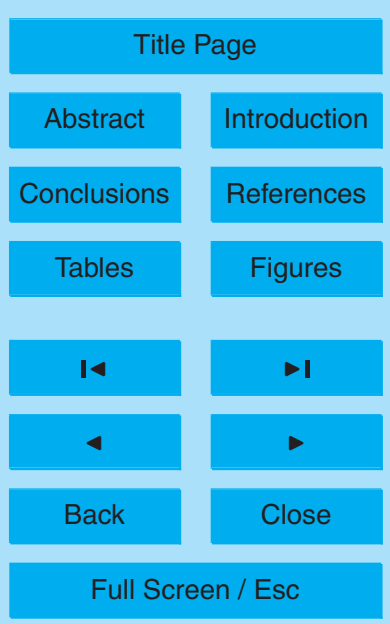

Printer-friendly Version

Interactive Discussion 


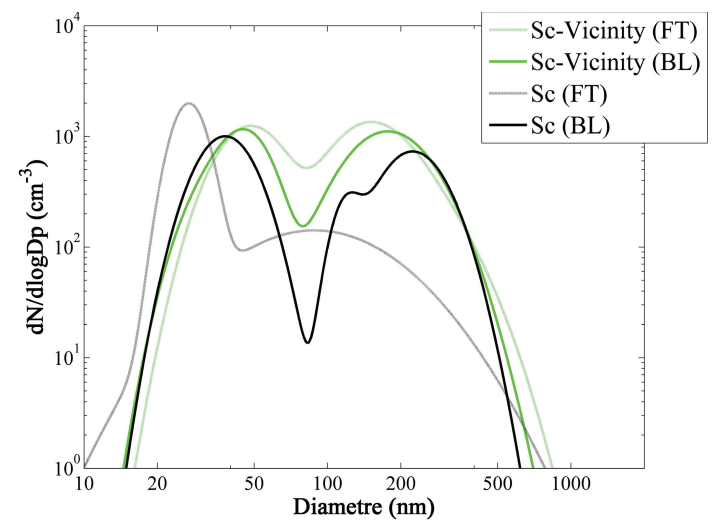

\section{ACPD}

$11,33229-33271,2011$

\section{Impact of cloud processes on aerosol particle properties}

S. Crumeyrolle et al.

(a)

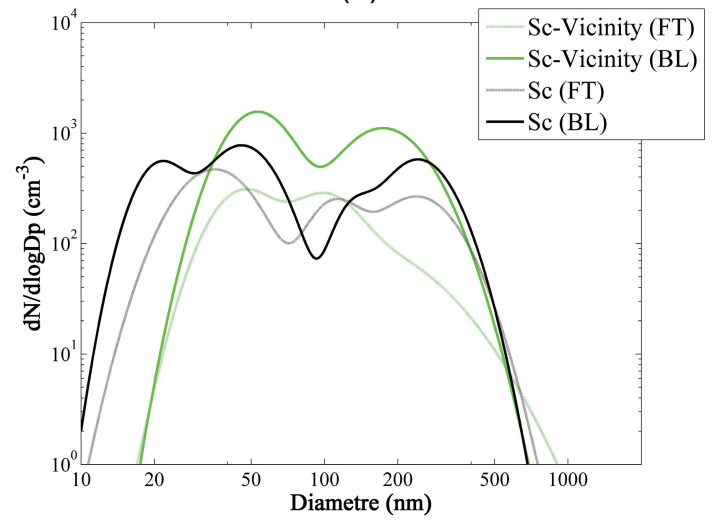

Title Page

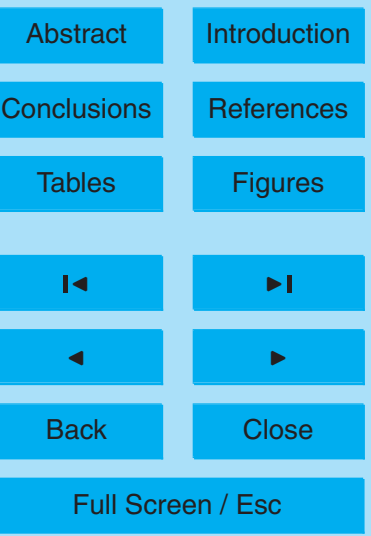

(b)

Fig. 5. Averaged number size distributions of particles observed during RF51 on 15 May in the morning (a) and during RF52 in the afternoon of the same day (b). Solid (light) lines represent measurements performed in the boundary layer (free troposphere). Green color corresponds to sc-vicinity measurements and black colour corresponds to above and below the stratocumulus cloud system. 


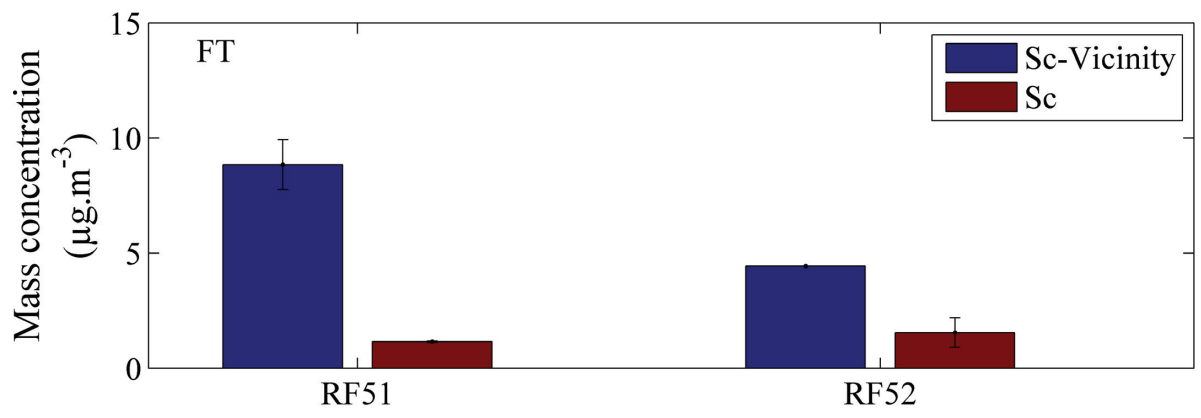

\section{ACPD}

11, 33229-33271, 2011

\section{Impact of cloud processes on aerosol particle properties}

S. Crumeyrolle et al.

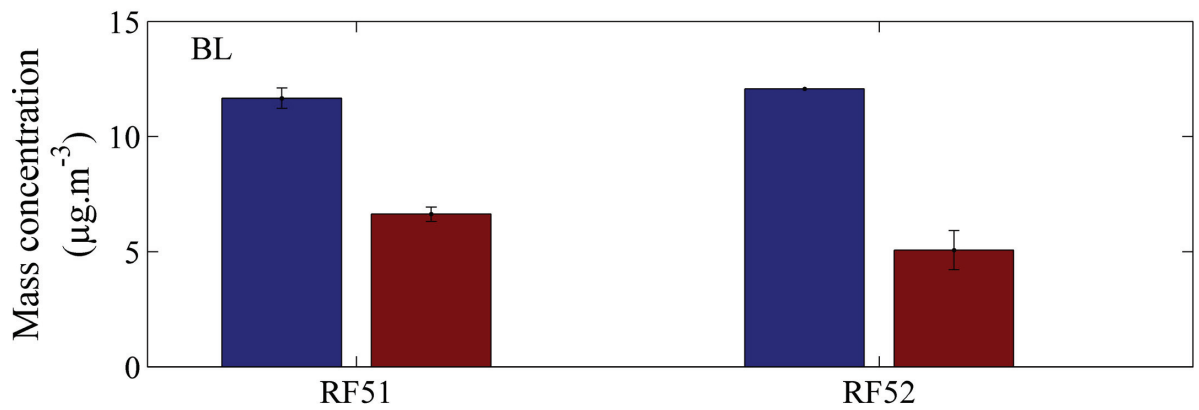

Title Page

Abstract Introduction

Conclusions

References

Tables

Figures

14

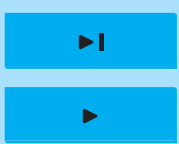

Back

Close

\section{Full Screen / Esc} sc-vicinity segments and below/above the stratocumulus cloud. The upper panel corresponds to the free troposphere measurements ( $1150 \mathrm{~m}$ a.s.I. for RF51 and $1250 \mathrm{~m}$ a.s.I. for RF52); the bottom panel corresponds to boundary layer measurements $(330 \mathrm{~m}$ a.s.l. for RF51 and $350 \mathrm{~m}$ a.s.I. for RF52). 


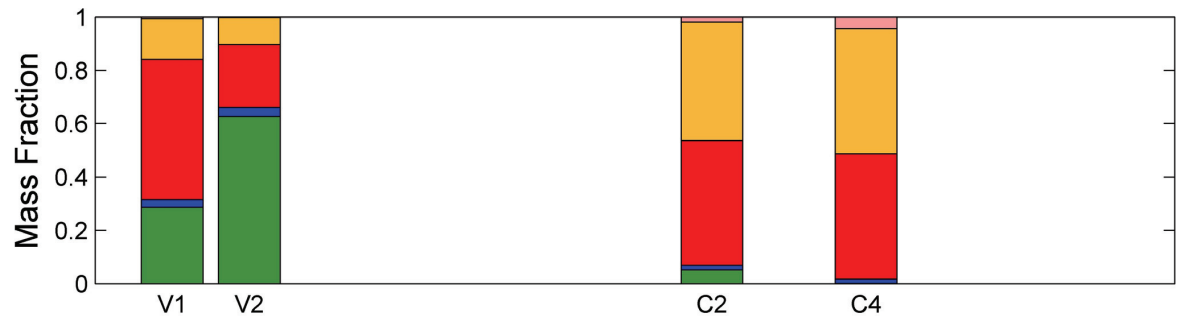

\section{ACPD}

11, 33229-33271, 2011

\section{Impact of cloud processes on aerosol particle properties}
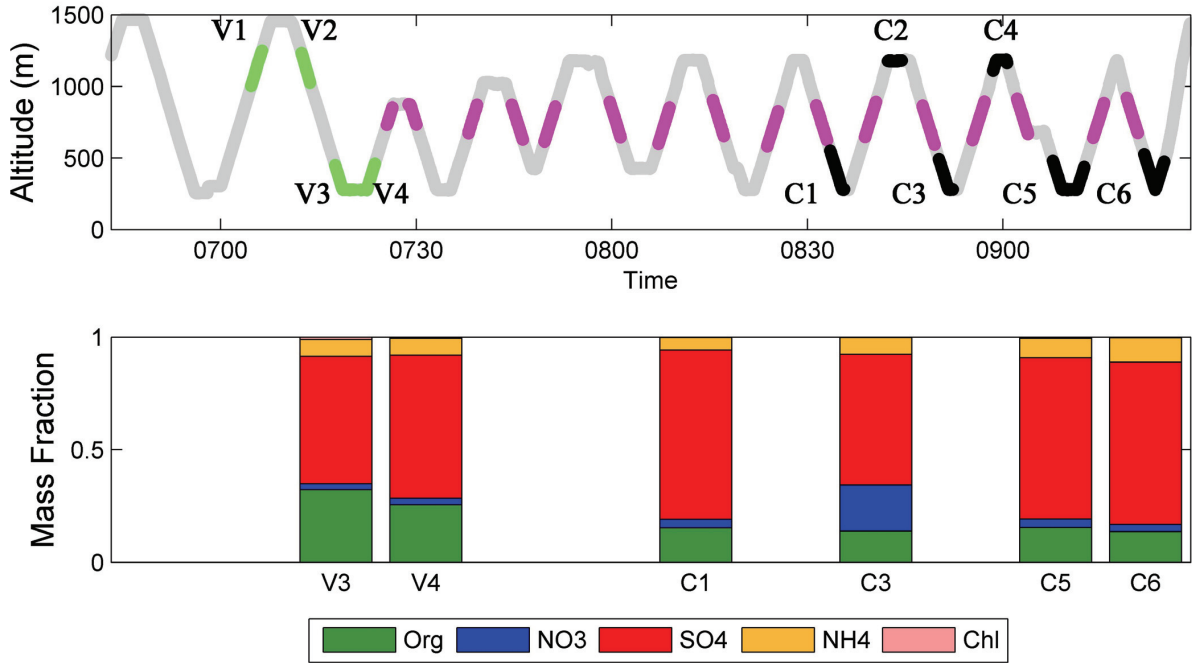

Fig. 7. Averaged particle chemical composition from CToF-AMS measurements for RF51, during sc-vicinity $(\mathrm{V} 1-\mathrm{V} 4)$, and below/above the stratocumulus layer $(\mathrm{C} 1-\mathrm{C} 6)$. Five chemical compounds are shown: Organics $(\mathrm{Org})$, Nitrate $\left(\mathrm{NO}_{3}\right)$, Sulfate $\left(\mathrm{SO}_{4}\right)$, Ammonium $\left(\mathrm{NH}_{4}\right)$ and Chloride (Chl). The upper panel corresponds to $1150 \mathrm{~m}$ a.s.l. flight altitude, the bottom panel corresponds to $350 \mathrm{~m}$ a.s.l. flight altitude.

S. Crumeyrolle et al.

Title Page

\section{Abstract}

Conclusions

Tables

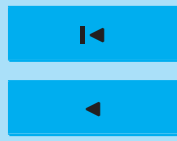

Back
Introduction

References

Figures

$>1$

$>$

\section{Close}

\section{Full Screen / Esc}

Printer-friendly Version

Interactive Discussion 


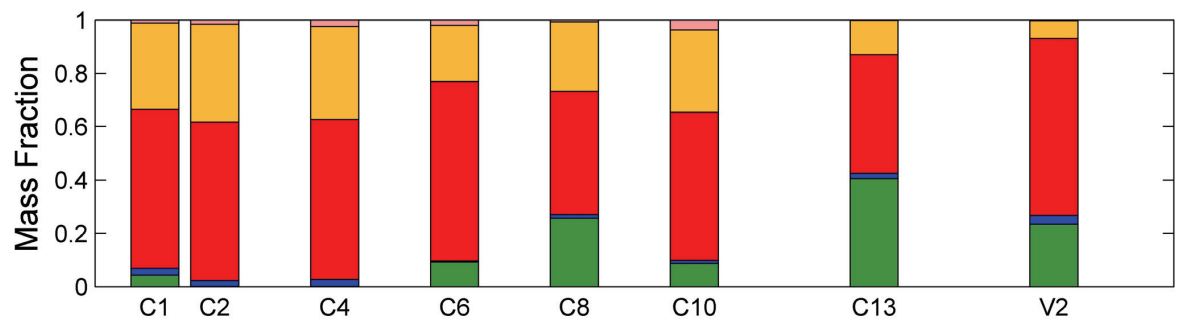

ACPD

$11,33229-33271,2011$

\section{Impact of cloud processes on aerosol particle properties}
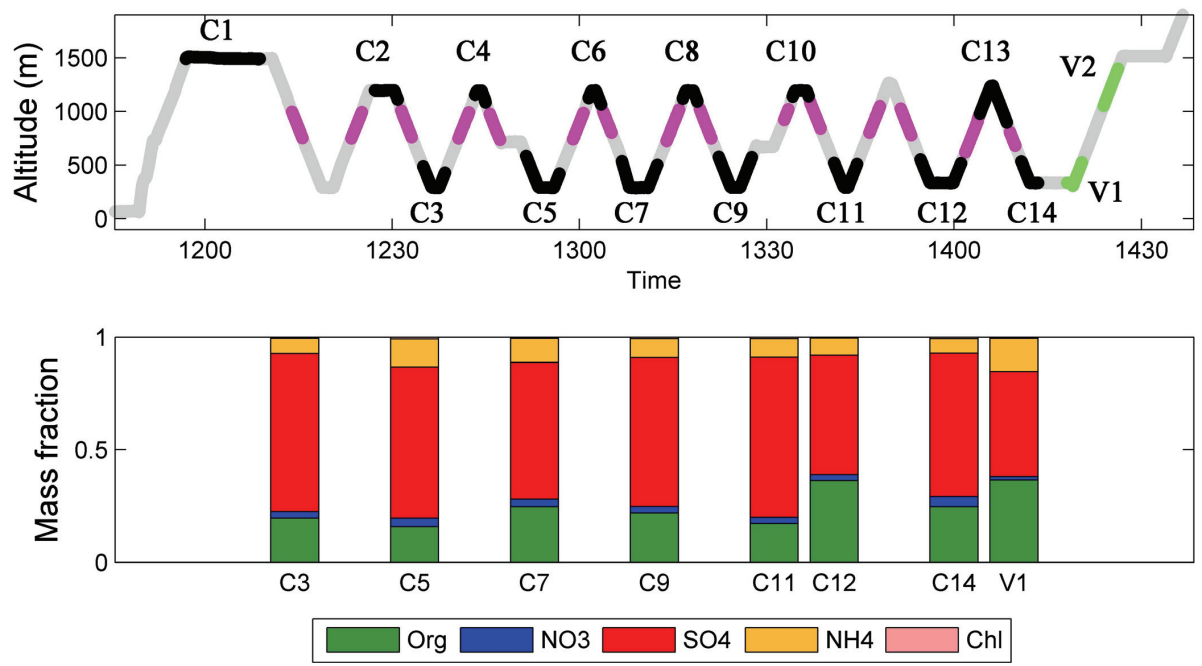

Fig. 8. Averaged particle chemical composition from CToF-AMS data for RF52, during scvicinity (V1-V2), and below/above the stratocumulus layer (C1-C14). The upper panel corresponds to $1250 \mathrm{~m}$ a.s.l. flight altitude, the bottom panel corresponds to $350 \mathrm{~m}$ a.s.l. flight altitude.

Title Page

Abstract Introduction

Conclusions References

Tables

Figures

14

4

Back

Close

\section{Full Screen / Esc}

Printer-friendly Version

Interactive Discussion 
a)

\section{ACPD}

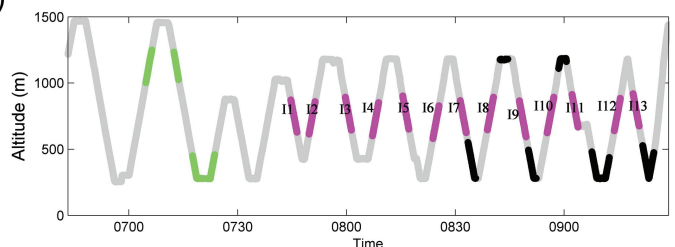

11, 33229-33271, 2011

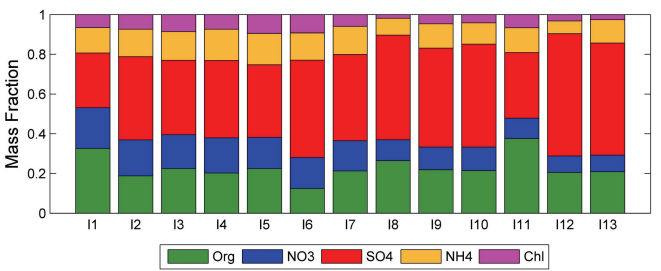

b)
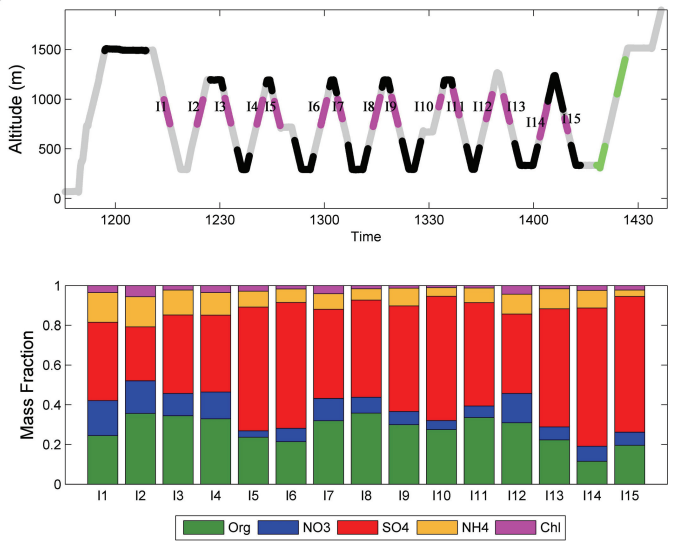

\section{Impact of cloud processes on aerosol particle properties}

S. Crumeyrolle et al.

Title Page

Abstract Introduction

Conclusions References

Tables

Figures

14

4

Back

Close

\section{Full Screen / Esc}

Printer-friendly Version

Fig. 9. Averaged particle chemical composition during in cloud conditions (I1-I13 and I1-I15, respectively) for research flights RF51 (a) and RF52 (b). The mass fraction figures correspond to about $800 \mathrm{~m}$ flight altitude. 

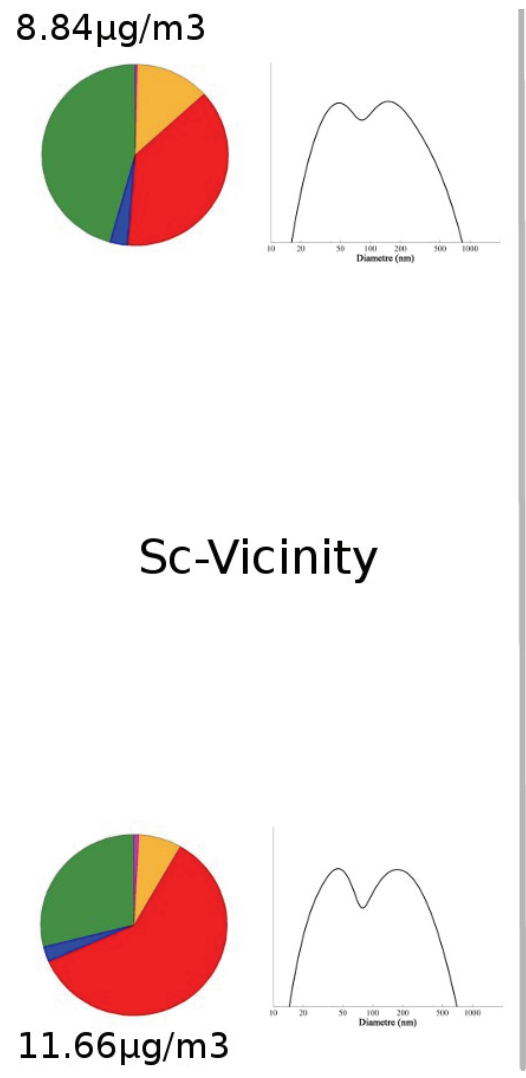

\section{$1.16 \mu \mathrm{g} / \mathrm{m} 3$}
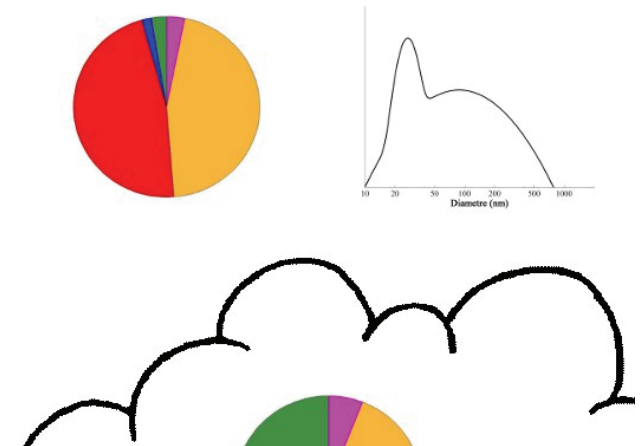

$3.92 \mu \mathrm{g} / \mathrm{m} 3$

Sc

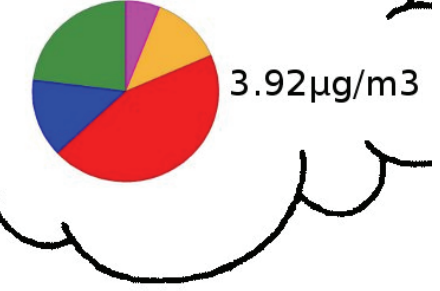

$6.58 \mu \mathrm{g} / \mathrm{m} 3$

Fig. 10. Summary of particle chemical composition from cToF-AMS measurements for research flight RF51 during sc-vicinity, below/above stratocumulus layer, as well as in-cloud analysis from CVI inlet at different altitude levels (lower layer at 300-600 m, cloud level 600-1000 m, and upper layer at $1000-1500 \mathrm{~m}$ ).
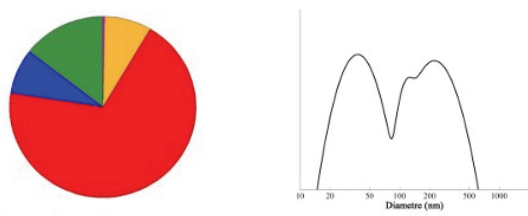

4

Back

Full Screen / Esc

Printer-friendly Version

Interactive Discussion 

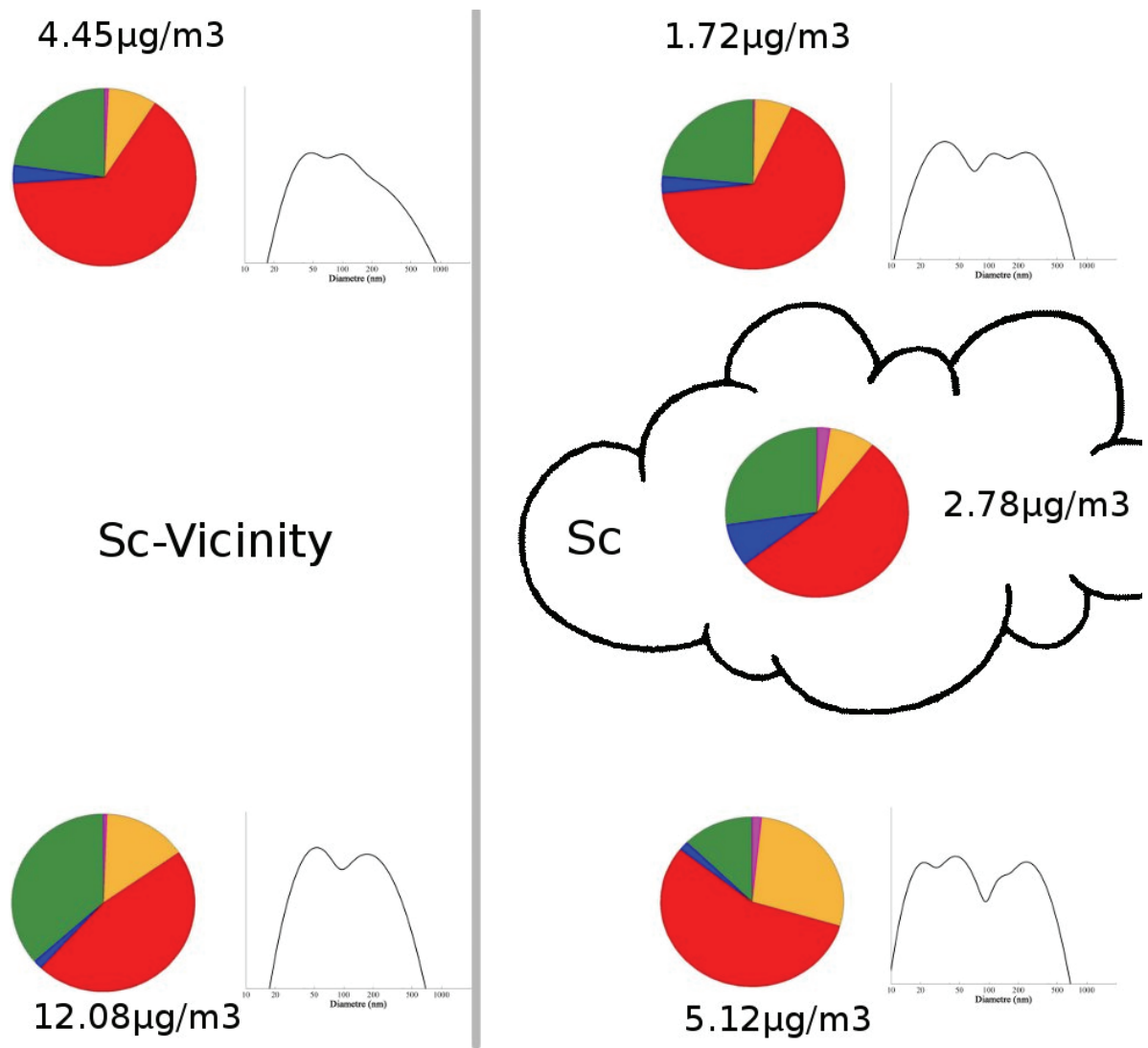

Fig. 11. Summary of particle chemical composition from cToF-AMS measurements for research flight RF52 during sc-vicinity, below/above stratocumulus layer, as well as in-cloud analysis from CVI inlet at different altitude levels (lower layer at 300-600 m, cloud level 600-1000 m, and upper layer at $1000-1500 \mathrm{~m}$ ).

\section{ACPD}

11, 33229-33271, 2011

\section{Impact of cloud processes on aerosol particle properties}

S. Crumeyrolle et al.

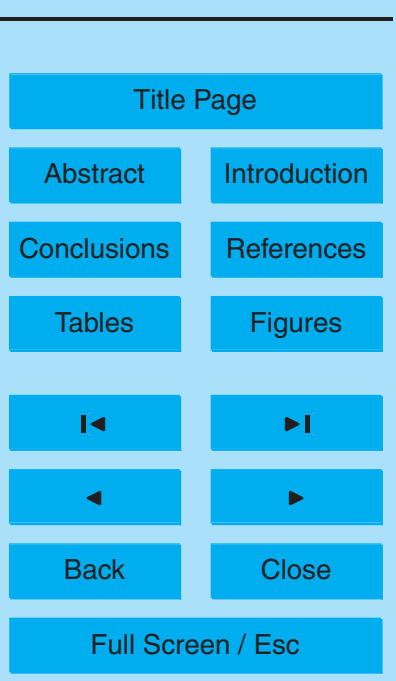

Printer-friendly Version

Interactive Discussion 